
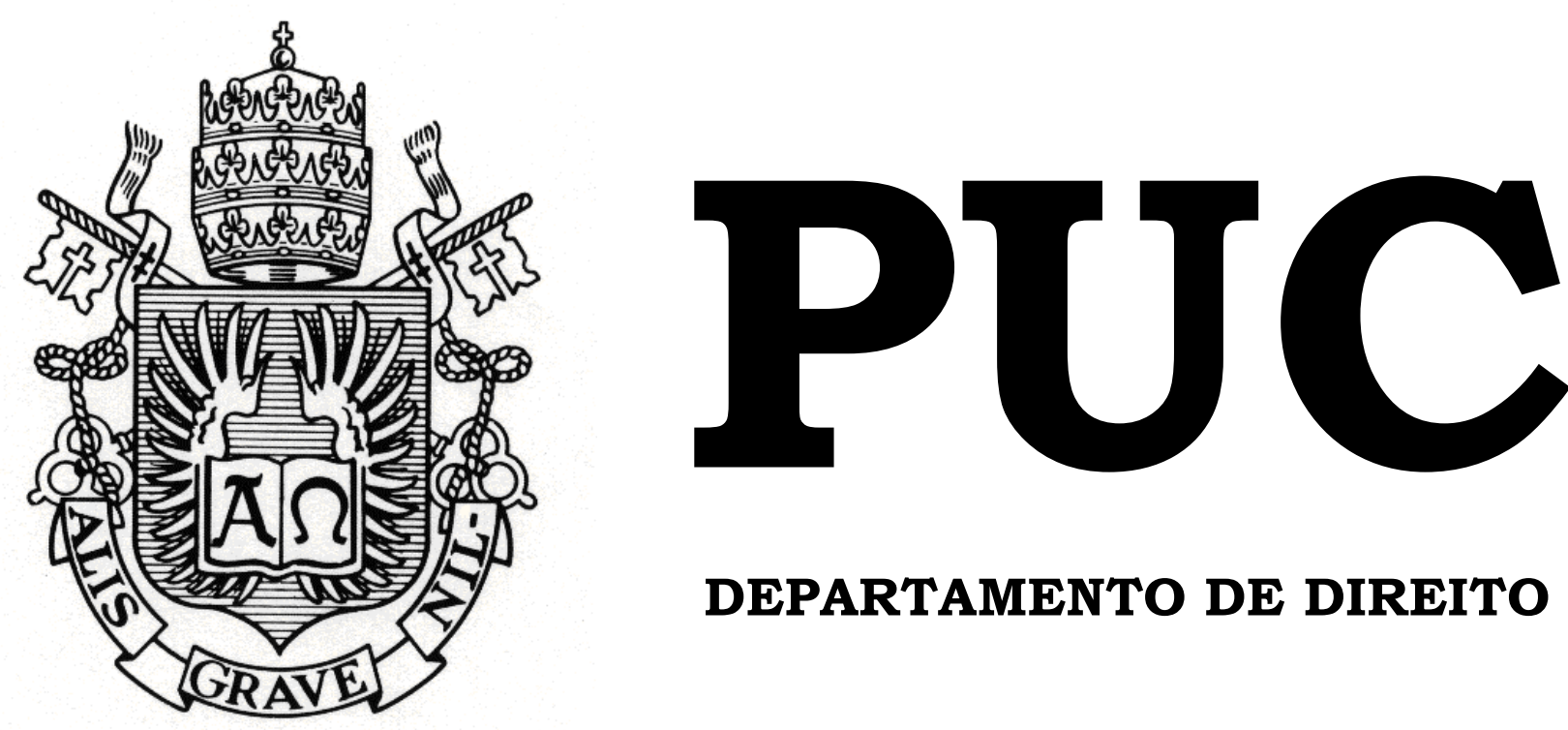

DEPARTAMENTO DE DIREITO

\title{
A DESJUDICIALIZAÇÃO DA USUCAPIÃO NO CONTEXTO FUNDIÁRIO DO BRASIL URBANO: NOVAS POSSIBILIDADES PARA GARANTIR $O$ DIREITO À MORADIA
}

por

FABRICIA MACHADO COELHO DE ANDRADE RAMOS

ORIENTADORA: Mariana Trotta Dallalana Quintans 2012.1

PONTIFÍCIA UNIVERSIDADE CATÓLICA DO RIO DE JANEIRO

RUA MARQUÊS DE SÃO VICENTE, 225 - CEP 22453-900

$$
\text { RIO DE JANEIRO - BRASIL }
$$




\title{
A DESJUDICIALIZAÇÃO DA USUCAPIÃO NO CONTEXTO FUNDIÁRIO DO BRASIL URBANO: NOVAS POSSIBILIDADES PARA GARANTIR O DIREITO À MORADIA
}

\author{
por
}

FABRICIA MACHADO COELHO DE ANDRADE RAMOS

Monografia apresentada ao Departamento de Direito da Pontificia Universidade Católica do Rio de Janeiro (PUC-Rio) para a obtenção do Título de Bacharel em Direito.

Orientadora: MARIANA TROTTA DALLALANA QUINTANS 


\section{DEDICATÓRIA}

Tenho medo. Medo de ti, sem te conhecer, medo só de te sentir, encravada favela, erisipela, mal-do-monte na coxa flava do Rio de Janeiro.

Medo: não de tua lâmina nem de teu revólver

Nem de tua manha nem de teu olhar.

Medo de que sintas como sou culpado e culpados somos de pouca ou nenhuma irmandade.

Favelário Nacional

Carlos Drummond de Andrade

Para que não tenhamos mais medo de seguir em frente na humanização desta cidade, dedico esta monografia a todos os meus irmãos e irmãs ainda na luta por suas casas e suas cidadanias. Estamos nessa juntos. 


\section{AGRADECIMENTOS}

Nunca pensei que depois de quase três anos pensando em mudar de curso eu fosse me reencontrar no Direito. Hoje, me formo desta faculdade com uma certeza: a de que eu não poderia ter feito outra. Por isso, inicio agradecendo aos meus pais, não apenas pela prioridade que sempre deram à minha formação, mas por todos os "ombros amigos" e empurrões encorajadores, me ensinando a terminar o que comecei, a dar segundas chances na vida e a tentar sempre, sabendo de que terá valido a pena mesmo se o resultado não seja o esperado.

Em seguida, dado o momento essencialmente acadêmico, aproveito para agradecer à todos os meus professores, da escola à vida, especialmente: à Kybran Phillips, por garantir meu pensamento crítico e o me ensinar o prazer que é estudar; à Patrícia Magalhães, por estourar uma bolha e me colocar em contato com o mundo; aos professores da Sciences Po, por terem me ressuscitado e me ajudado a colocar o Direito em perspectiva; à Maria Alice Rezende de Carvalho, por me dar uma das melhores aulas nesta Universidade e, nela, me ajudado a descobrir o poderoso elo entre Direito e Sociedade no contexto urbano; à Augusto César Pinheiro, por me "colocar no meu lugar" - o Rio de Janeiro - e por abrir meus olhos para o tamanho da nossa cidade, inteira maravilhosa, e para a importância do planejamento; à Mauricio Rocha e Pedro Villas Boas, apesar dos breves encontros, por sua bravura em ensinar disciplinas tão centrais e tão desvalorizadas pelos alunos e pelo mercado, me ajudando a sobreviver em meio a técnica e a lógica; à Alexandre Assed, por me encher de vontade de praticar a advocacia, por quebrar o pacto de mediocridade e por tornar aulas sábado de manhã suportáveis; à José Arnaldo Rossi, por me mostrar que a vida, com seus infinitos rumos e desvios, é, essencialmente, humana e deve ser vivida sem medo; e, por fim, à Mariana Trotta, por ter me guiado nesta nova paixão - o Direito Fundiário - e por sua paciência comigo.

Por fim, quero agradecer ao CAEL, pela minha primeira experiência política, pelas pessoas maravilhosas que me trouxe e pelas infinitas lições que nele aprendi: espero, mesmo sabendo que é impossível, ter contribuído à altura. 


\section{RESUMO}

Construção histórica dos conceitos de posse e propriedade, culminando com a consagração da última - direito natural e fundamental - em detrimento da primeira, mero fato ou exercício do domínio. Funcionalização dos direitos: a relativização da propriedade liberal. Propriedade como direito-dever após a Constituição de 1988. Reestruturação do conceito e adaptação do ordenamento pela função social do artigo $5^{\circ}$, XXIII. A usucapião como única forma de aquisição da propriedade pela posse historicamente reconhecida na lei brasileira. A usucapião especial como remédio legal para a concentração fundiária herdada da colonização pelo regime de sesmarias. Terra e lei no Brasil à luz da ambiguidade legislativa e da criação de entraves técnico-jurídicos irresolúveis. O desenvolvimento da questão urbana a partir do fracasso da regularização fundiária do campo. A Lei de Terras e a terra como mercadoria: a legalização exclusivamente por título hereditário ou compra. Insuficiência da legitimação de posse para obtenção do título proprietário. Inacessibilidade à terra e êxodo rural. Apropriação do solo urbano e generalização do sistema de posses nas cidades. $\mathrm{O}$ surgimento do Direito Urbanístico com a especialização da legislação a partir da Lei do Parcelamento do Solo Urbano de 1979. O agravamento do déficit habitacional e das irregularidades fundiárias e a nova política urbana: o Estatuto da Cidade. Os entraves e a ineficácia do Judiciário e a desjudicialização da usucapião pela Lei $n^{\circ}$ 11.977/2009 como alternativa.

Palavras-chave: REGULARIZAÇÃO FUNDIÁRIA. FUNÇÃO SOCIAL DA PROPRIEDADE. LEGITIMAÇÃO DE POSSE. DESJUDICIALIZAÇÃO DA USUCAPIÃO. LEI FEDERAL No 11.977/2009. 


\section{SUMÁRIO}

$\begin{array}{lc}\text { INTRODUÇÃO } & 6\end{array}$

$\begin{array}{lr}\text { CAPÍTULO } 1 & 10\end{array}$

Posse e propriedade na usucapião: definições e funções sociais

1.1 Origem da noção de propriedade em detrimento da 12 posse: do antecedente romano à teoria objetiva de Ihering

1.2 O individualismo dobra a esquina: a funcionalização da 20 propriedade e refundação da ordem na solidariedade social

\section{CAPÍTULO 2}

Terra e Lei no Brasil: a ambiguidade da legislação fundiária e a construção da questão urbana

2.1 A posse e a propriedade na origem da questão da terra brasileira

2.2 Do campo à cidade: a exclusão da posse como meio de acesso ao solo e seus desdobramentos

2.3 Remédios legais para problemas urbanos: o novo aparato jurídico para lidar com as 'selvas de pedra'

\section{CAPÍTULO 3}

A Lei $n^{o} 11.977$ de 2009 e o processo administrativo para a usucapião em âmbito urbano

3.1 O fenômeno da desjudicialização no ordenamento jurídico brasileiro e o impacto sobre os registros públicos

3.2 O procedimento administrativo da usucapião urbana: a legitimação de posse e seus efeitos

3.3 Velhos entraves em novas ideias? O alcance da ambiguidade legislativa brasileira nas recentes leis urbanísticas 


\section{INTRODUÇÃO}

O solo é incomensurável no seu valor, tanto para os particulares, como para o povo em seu conjunto [...] $O$ solo é toda a hipótese e possibilidade de vida (Hedemann, 1995, p. 283 apud Lira, 1997, p. 108). Para o presente trabalho de conclusão do curso de Direito, a escolha pela temática central - o acesso ao solo urbano - se deu em grande parte pela magnitude da questão: o solo é essencial à vida por viabilizar, sobretudo, o assentamento humano, sem o qual não se pode florescer a sociedade, nem existir o indivíduo. No entanto, mesmo diante deste fato, o solo continua a ser, no mundo contemporâneo, uma mercadoria, uma commodity cujo preço não está atrelado à sua função vital.

Originalmente uma questão do campo, a luta pelo acesso ao solo ganha novas proporções ao se reproduzir nas cidades: no Brasil, o processo de intensa urbanização que ocorreu a partir do século XX foi deflagrado pelo êxodo rural daqueles que - não dispondo de terra nem meios para plantar e não encontrando trabalho cujo salário correspondesse à dignidade humana abandonam o campo rumo às grandes cidades. Explica o professor Edésio Fernandes (2007, p. 19):

Ao longo das décadas de crescimento urbano, mas, sobretudo, nas duas últimas décadas, dezenas de milhões de brasileiros não tiveram acesso ao solo urbano e à moradia, senão por meio de processos e mecanismos informais - e ilegais. Favelas, loteamentos e conjuntos habitacionais irregulares, loteamentos clandestinos, cortiços, casas de fundo.

Assim, este trabalho terá como pano de fundo a situação atual dos centros urbanos brasileiros, nos quais a moradia, elemento básico do desenvolvimento humano, só pode ser garantida para milhares de pessoas em assentamentos irregulares e precários que não estão adequados aos padrões de infraestrutura urbana e serviços básicos partilhados pelas áreas formalmente constituídas. O cerne da questão urbana é - como na questão agrária - a tensão existente entre a legalidade fundada em títulos e a ilegalidade gerada pela necessidade. É neste sentido que cabe dizer o óbvio: morar não é uma escolha; todo ser humano, ao nascer, passa a necessitar de moradia. No entendimento de 
Henri Lefebvre (1999), ainda, o conceito de "casa" é complementar à própria condição humana, sendo fator essencial para o desenvolvimento da personalidade, da intimidade e da sociabilidade.

Entendendo a habitação como uma necessidade, a noção de moradia ilegal se aproxima de uma verdadeira contradição: mesmo após ser consagrada um direito social - e, ainda merecendo ser alçada à direito fundamental - a habitação no Brasil é sinônimo de déficit. O déficit, por sua vez, é sintomático de uma conjuntura em que as leis, a atuação do Poder Público e os entendimentos judiciais não promovem de forma objetiva a concretização do direito à moradia. Neste trabalho, portanto, o objetivo é investigar o primeiro dos elementos citados: em que medida as leis contribuíram para a generalização das moradias ilegais e irregulares.

A análise da legislação, que levará em consideração os diferentes contextos históricos em que esta foi produzida, me permite abordar mais diretamente a ligação entre os conceitos de propriedade e posse e a efetivação da regularização fundiária no Brasil. Dessa forma, pretende-se buscar entender porque que, desde a colonização, fracassamos em distribuir a terra de forma mais equânime e, assim, falhamos na construção de um sistema de propriedade inclusivo e regularizado. Parte-se, portanto, da hipótese de que o quadro de déficit habitacional e moradia ilegal é produto da consagração da propriedade formalista e liberal em detrimento da posse, na medida em que apenas os títulos herdados e a compra e venda foram reconhecidos pela lei brasileira como meios de legítimos para se adquirir legalmente o solo, equiparando-o, inegavelmente, a uma mercadoria.

Situação de fato, a posse nunca precisou de autorização legislativa para se consumar. Por isso, diante das complicações legais enfrentadas pelo homem médio brasileiro - o trabalhador - na aquisição de uma parcela de terra para o cultivo ou a moradia, a posse se tornou forma comum, porque possível, de apropriação do espaço aparentemente livre, tanto no campo quanto nas cidades. Historicamente, a única forma prevista de transformação da posse em 
propriedade - reconhecendo-a como forma legítima de aquisição do solo - é a usucapião, instrumento milenar de garantia do aproveitamento da terra e, assim, embrião da noção de função social da posse e da propriedade. No Brasil, a usucapião está expressamente prevista no ordenamento brasileiro desde seu regramento no Código Civil de 1916, sendo a única forma de formalização das ocupações para fins de cultivo e moradia que não dispunham de título prévio.

Posse, propriedade e usucapião, portanto, serão os principais conceitos jurídicos abordados no primeiro capítulo deste trabalho, visando compreender como que estes influenciaram a formação fundiária do país a partir de suas definições, e a variação destas, nas leis brasileiras. Em seguida, partindo da hipótese apresentada por James Holston (1993), o segundo capítulo do trabalho pretende analisar as principais leis nacionais - das gerais como as Constituições e os Códigos Civis às especificamente fundiárias - à luz da ambiguidade de seus textos. Para o referido autor, que servirá de base para esta análise, mesmo não sendo a legislação a única responsável pelos conflitos fundiários, é ela quem permite e sustenta a confusão quanto ao direito ao solo e a sua inacessibilidade a partir da criação de procedimentos e trâmites irresolúveis pelos tribunais.

A moradia ilegal é uma maneira comum e segura através da qual a classe trabalhadora pode ganhar o acesso legal à terra e à moradia, acesso esse que, de outro modo, não seria possível. Assim, uma relação fundamental entre usurpação e legalização caracteriza o desenvolvimento da periferia: a usurpação inicia o povoamento e desencadeia o processo de legalização da propriedade da terra. É importante acrescentar que essa relação se cristalizou no começo da colonização brasileira como uma estratégia das elites fundiárias e dos especuladores imobiliários, que dela se serviram para arrancar ganhos incalculáveis. Durante séculos eles a usaram não somente para ampliar seus negócios comerciais, mas também pra consolidar uma enorme concentração de propriedades. Na verdade, [...] a lei da terra brasileira foi montada para ser cúmplice dessa prática, e não um obstáculo a ela. [...] Essa investigação também revela que as grilagens de terras atuais repetem velhos esquemas, com uma diferença: os pobres hoje competem regularmente nas arenas legais das quais eles tinham sido excluídos - não porque a lei está agora mais preocupada com a justiça ou com soluções, mas porque eles aprenderam, muito em função das disputas de terra, a usar as complicações da lei para obter vantagens extralegais (Holston, 1993). 
Nesta perspectiva, a onda de desjudicialização de alguns processos de cunho patrimonial no Brasil traz novo fôlego para a discussão: diante do procedimento extrajudicial instituído pela Lei $\mathrm{n}^{\circ} 11.977$ de 2009 para o reconhecimento da usucapião, terá a legislação brasileira finalmente vencido os obstáculos autoimpostos para a regularização fundiária do país? É o tema do terceiro capítulo desta monografia, que, partindo do texto da referida lei, irá analisar seu potencial para a aceleração do processo de reconhecimento da posse como meio legítimo de garantia da habitação.

Entende-se, portanto, que o desafio jurídico atual é reverter este quadro de ilegalidades e irregularidades que atentam contra direitos básicos como a dignidade da pessoa humana, mantendo milhões de brasileiros em situações de moradia precária e insegura, sem acesso à infraestrutura nem serviços urbanos adequados. A retrospectiva histórica dos conceitos e legislações a seguir, portanto, pretende resgatar como chegamos ao ponto em que nos encontramos: um emaranhamento social e jurídico nas cidades que parece resistir às meras fórmulas legislativas, tal como fez a estrutura fundiária do campo. Finalmente, parece que os diplomas legais, as posturas judiciais e os investimentos administrativos estão se voltando cada vez mais para a efetivação da regularização fundiária urbana, tamanha é a evidência do problema da moradia e da crise de sustentabilidade das metrópoles. 


\section{CAPÍTULO 1}

\section{Posse e propriedade na usucapião: definições e funções sociais}

A origem histórica e filosófica da propriedade é, senão, a posse: a noção de submissão da coisa a um sujeito de direito se inicia com o apossamento privado dos recursos disponíveis. O próprio desenvolvimento da sociedade começa com a fixação de um grupo de homens e mulheres em determinado local, o que significa que as raízes da sociedade e da apropriação do solo, portanto, são interligadas - ou mesmo, estas teriam a mesma raiz. Neste momento, porém, o regime de propriedade privada ainda não havia se generalizado, permitindo o desenvolvimento, ao longo da história, de milhares de sociedades primitivas e antigas sustentadas sobre noções comunitárias e comunais de propriedade. Mesmo assim, a noção de origem da propriedade privada mantém-se atrelada à posse, no sentido ilustrado por Jean-Jacques Rousseau, talvez sem o perceber, em seu Discurso sobre as origens e os fundamentos da desigualdade entre os homens (1754):

O primeiro que, tendo cercado um terreno, atreveu-se a dizer: isto é meu, e encontrou pessoas simples o suficiente para acreditar nele, foi o verdadeiro fundador da sociedade civil. Quantos crimes, guerras, assassínios, quanta miséria e horrores não teria poupado ao gênero humano aquele que, arrancando as estacas ou enchendo o fosso, houvesse gritado aos seus semelhantes: evitai ouvir esse impostor. Estareis perdidos se esquecerdes que os frutos são de todos e que a terra não é de ninguém! (Rousseau, 1754, trad. Galvão, 2008, p. 203).

Identificado com a corrente liberal que prevaleceu no período referido como o Iluminismo, Rousseau pensou a propriedade privada como o próprio fundamento do pacto social, tendo a mesma importância, assim, que os direitos que este pacto procurava garantir, como a liberdade e a vida. No entanto, na própria passagem em que descreve o surgimento da propriedade, Rousseau está, de fato, consagrando a posse como sua força geradora, como sua origem, sua essência primeira. No entanto, no mesmo momento em que se reconhece que a posse é a origem da propriedade, esta se descola daquela, tornando-se autônoma, consagrando-se direito abstrato, enquanto a posse permanece um 
mero fato. Em termos filosóficos, portanto, a propriedade, essencialmente, iniciou-se pela usucapião, instituto pelo qual a posse é forma aquisitiva originária de propriedade, sendo, assim, a cristalização jurídica do primeiro momento em que se criou este consagrado direito (Fachin, 1988, p.13).

Como ensina o professor e Procurador do Estado Miguel Baldez (1997, p. 9):

Como ponto de partida cabe fazer uma distinção conceitual entre posse e propriedade, sendo a posse uma relação de fato entre o homem e a terra, e a propriedade uma relação jurídica criada pelo Direito Burguês para garantir, à distância, o domínio sobre a terra. Explica-se: na transição, no ocidente, do modo de produção feudal para o modo de produção capitalista, com a transferência da estrutura econômica da sociedade do campo para a cidade, era fundamental para a classe que se qualificaria como dominante garantir a titulação sobre o monopólio da terra. Enquanto a essência da produção estava no campo, enquanto não se tinha ainda caracterizado a cidade como espaço produtivo, não se teve a preocupação de distinguir com clareza entre posse e propriedade. Essa necessidade só foi aparecer naquele momento de transição, pois, como se disse acima, saindo do campo para a cidade os que haviam acumulado a riqueza precisavam encontrar o meio adequado de ficar na terra sem estar fisicamente nela. Somente um artifício jurídico seria capaz de assegurar esse resultado, o vínculo jurídico da propriedade, mera abstração.

Não obstante ferrenhos argumentos contra a propriedade privada, feitos por filósofos como Jean-Pierre Proudhon, em $O$ que é a propriedade, ou, Pesquisa sobre o Princípio de Direito e de Governo (1840), esta se firmou como base da ordem social ocidental, consagrando-se ainda na passagem para o século XIX, com as revoluções norte-americana e francesa, culminando, juridicamente, com o Código de Napoleão (1804). A consagração moderna da propriedade, no entanto, não se fez apenas com base na filosofia liberal de pensadores como Rousseau e John Locke - que em seu Second Treatise of Government (1689), entende a propriedade privada como uma exigência natural do ser humano, necessária para a subsistência do indivíduo, adquirida e legitimada por seu trabalho, pela força emanada de seu corpo (apud Comparato, 1998) - tendo estes mesmos autores recorridos aos fundamentos proprietários do Direito Romano. A base jurídica romana irá legitimar a nova organização social que começa a se moldar no século XIX em torno da 
proteção da propriedade privada (leia-se, individual) como regime adequado para garantir a liberdade, a igualdade e a pacificação social. No entanto, é neste mesmo antecedente histórico romano que a propriedade irá encontrar sua maior limitação - o embrião da função social contido na usucapião - que, elevada ao nível de direito fundamental no século XX, irá reestruturar seu significado e afetar a sua proteção.

Assim, este capítulo pretende trabalhar a consagração jurídica e historicamente construída da propriedade em detrimento da posse, do Direito Romano ao Código de Napoleão, e como que esta corrente se firmou e se reproduziu nas Constituições brasileiras, a partir das diferentes conjunturas internacionais e nacionais que ocorreram ao longo dos séculos XIX e XX. Paralelamente, o capítulo também dará destaque para a construção da noção de função social como verdadeiro fator de relativização da propriedade, especialmente urbana, abordando desde de seu embrião na natureza da usucapião, à sua consagração como direito - que, no Brasil, ocorre na Constituição de 1988, apesar de constar como princípio da ordem econômica e social desde 1946 -, até seus desdobramentos urbanísticos, como a edificação compulsória e o IPTU progressivo, no caso do nosso ordenamento.

\subsection{Origem da noção de propriedade em detrimento da posse: do antecedente romano à teoria objetiva de lhering}

Como conceito jurídico, a propriedade teve - e ainda tem - contornos e tratamentos diversos conforme o local e a época de seu ordenamento. No século XVIII, momento em que se desencadeou o processo de formação dos Estados europeus e norte-americano com base em constituições jurídicas, a propriedade privada foi consagrada como direito fundamental absoluto e ilimitado, o que lhe deu mais autonomia e maior valor de que gozava o instituto da posse. A nova ordem sociopolítica e econômica que substituiu o sistema feudal na Europa e fundou os Estados Unidos da América - o Estado-Nação, a sociedade burguesa e a economia capitalista - trouxe em seu bojo a 
propriedade privada como instrumento de proteção da liberdade e do indivíduo, e a partir da qual a ordem e a segurança seriam garantidas. É nesta linha que Rousseau (apud Comparato, 1998), considera a propriedade como um direito natural, imprescritível e inerente ao homem e ao pacto social:

No Discurso sobre a economia política
$[1755]$, publicado na Encyclopédie,
considerou "certo que o direito de
propriedade é o mais sagrado de todos os
direitos dos cidadãos e mais importante, de
certa forma, que a própria liberdade. É
preciso relembrar aqui, insistiu, que o
fundamento do pacto social é a propriedade
[...]". Em outro escrito, incluído entres os
seus Fragmentos Políticos, o grande
genebrino chegou mesmo a afirmar que
"fundando-se todos os direitos civis sobre o
de propriedade $[. .] "$.

Assim, para os jusnaturalistas liberais daquela época, o novo conceito de propriedade privada foi construído a partir das noções clássicas de universalidade, atemporalidade e imutabilidade atreladas aos direitos naturais. Criaram, além disso, uma ponte com a noção proprietária romana, onde, em geral, tal instituto era entendido como poder jurídico soberano e exclusivo do sujeito titular sobre coisa determinada. Em Roma, a propriedade era prerrogativa exclusiva de uma classe aristocrata, nobre ou favorecida e considerada absoluta em termos de único poder incidente sobre a coisa, imune perante o Estado e demais particulares, ilimitada em sua exploração, e íntima em sua relação com o proprietário (Comparato, 1998). No entanto, esta visão da propriedade romana - apropriada pelos liberais como antecedente histórico da propriedade privada moderna - esconde as ressalvas já existentes sobre a propriedade na Roma antiga.

Buscando estudar a construção conceitual e a origem da posse, Ana Rita Albuquerque (2002, p. 61), conclui que, "tem-se que a origem da posse remonta à origem mesma da espécie humana, mas a necessidade de sua proteção ocorreu apenas após a promulgação da Lei das XII Tábuas”. Assim, percebe-se que a mesma sociedade que consagrou a propriedade como poder ilimitado e direito absoluto sobre a coisa, positivou, no artigo $5^{\circ}$ da Tábua VI 
da Lei das XII Tábuas (455 a.C.), a posse como forma de aquisição da propriedade por usucapião: "as terras serão adquiridas por usucapião depois de dois anos de posse, as coisas móveis depois de um ano" (Vieira, 1984). Mesmo que esta não seja - como contestam alguns - a primeira positivação da usucapião, a Lei de XII Tábuas serve como marco ilustrativo da antiguidade deste instituto e do embrião que carrega: a função social da propriedade.

A partir deste momento, o conceito de posse no Direito Romano passou por três fases: a primeira, em que a posse é uma soberania de fato e passa a se diferenciar juridicamente de outros institutos como uso e usufruto; a segunda, quando a posse passa a diferir da detenção por haver um ânimo dominial no possuidor, introduzindo o elemento subjetivo (animus possidendi) no conteúdo da posse; e a terceira, onde "a verdadeira posse [...] é aquela que é acompanhada da senhoria jurídica, ou que seria apta a tornar-se uma senhoria jurídica através da usucapião" (Albertario, 1941, p. 111-128 apud Albuquerque, 2002, p. 63-64). Esta última fase diz respeito à vigência do Corpus Iuris Civilis (528 d.C.), denominada também fase justinianéia, de onde “advém a expressão ius relativa à posse, ou seja, o ius possessionis ou o direto à posse e que se contrapõe à concepção clássica da posse como mero fato" (Albuquerque, 2002, p. 65-66). Tal direito à posse era geralmente entendido como direito aos interditos possessórios previstos no Direito Romano e direito à usucapião conforme a lei. ${ }^{1}$

A usucapião - aquisição da propriedade plena pela posse mansa e pacífica de determinado imóvel ou parcela de terra durante período definido em lei - em sua natureza transformadora e, inaugurando novo direito, originária, se baseia - tem sua natureza - na função social tanto da posse, quanto da propriedade. O que legitima a transformação da propriedade é a posse com uso, o que pode ser considerado uma redundância na medida em que se reconhece no próprio conceito de posse dar uso ao que se possui, diante da inexistência dessa presunção quando se fala de propriedade. Tanto é assim que a função

\footnotetext{
${ }^{1}$ É desta fase também que surge a noção de possessio iuris, a posse de determinado direito (Albuquerque, 2002, p. 65).
} 
social da posse não encontra-se positivada em nenhum dos diplomas referidos neste trabalho, mas é dedutível do ordenamento que consagra tal função para a propriedade.

As teoria sobre os fundamentos da usucapião são divididas em duas correntes: as teorias subjetivas calcadas no ânimo de renúncia ao direito por parte do proprietário que não o exerce, e as teorias objetivas que se fundamentam em considerações de utilidade social. O professor Caio Mário, acerca da matéria, afirma que ao fundamento ético da usucapião a tendência moderna imprime cunho nitidamente objetivo, considerando a função social da propriedade (Fachin, 1988, p. 37).

Neste segundo sentido, neste trabalho, a usucapião é entendida, como a institucionalização das funções sociais da posse e da propriedade, que se realizam vis-à-vis. Aproveitada a terra pelo cultivo e/ou estabelecida a moradia, dado seus relevantes sentidos sociais, legitima-se o domínio pleno sobre o bem, realiza-se a função da propriedade por meio da posse. Por outro lado, a teoria subjetiva que enfatiza a renúncia do proprietário ao não exercer o seu direito, não é mutuamente exclusiva em relação à primeira aqui prevalecente. Mesmo baseada na utilidade social, a usucapião sempre prevê um prazo considerado razoável para que o proprietário exerça suas faculdades, evitando ou interrompendo a posse de outros sobre seu bem. Assim, presume-se que quando o bem é usucapido por ter função social, o proprietário também abriu mão de exercitar seu poder ou cumprir o seu dever como tal. Caso contrário, apenas a utilidade pública mal distinguiria a usucapião da desapropriação.

$\mathrm{Na}$ adoção da herança romana como fundação da ordem pós-medieval do século XVIII, que vai culminar com o surgimento de diversos Estados e na consequente adoção do modelo republicano ao longo dos séculos XIX e XX, esse reconhecimento jurídico inicial dado à posse não foi reproduzido. $\mathrm{Na}$ vigência do sistema feudal ao qual o Iluminismo pôs fim, a inacessibilidade da terra pela maioria da população europeia de servos ou escravos era devida à concentração desta na mão de poucos nobres senhores ou príncipes. Esta situação levou à invasões e à posses ilegítimas, que acabaram gerando um sistema fundiário dual, que aceitava a sobreposição de direitos reais incidindo 
no mesmo bem, havendo o 'domínio eminente', resguardado pelo senhor como propriedade, e o 'domínio útil', como a cessão da posse para o ocupante. Assim, a distribuição de terra era feita por concessões ao longo da hierarquia da nobreza - de Rei à Duque à Conde e assim sucessivamente até o vassalo constituindo uma forma de enfiteuse própria deste período, mas que é exportada durante a colonização européia.

Reservando a camada mais abstrata da propriedade para o Rei - uma vez que na monarquia absolutista tudo era, em última instância, pertencente à Coroa - o sistema feudal permitiu que a concessão de parte do domínio para outrem significasse a incidência de dois poderes simultâneos sobre a coisa, diferenciados frequentemente ao longo da linha propriedade "versus" posse. Baseado principalmente pelo direito canônico e os costumes e tradições, o ordenamento feudal afastava ainda mais o caráter absoluto da propriedade sem negá-la ou abolir sua exclusividade classista - atribuindo ao seu titular obrigações perante seus dependentes, os camponeses e servos, criados e parentes, corte e amigos. O poder do nobre senhor de terras era garantido a partir da autoridade à este cedida pelo Rei e da produtividade de suas terras, gerando riquezas e sustentando a todos que dele dependiam. Assim, o domínio fundiário era a principal fonte de poder e de organização social, sendo a terra a mais valorada propriedade do período feudal.

A medida de riqueza era determinada por um único fator - a quantidade de terra. Esta era, portanto, disputada continuamente não sendo por isso de surpreender que o período feudal tenha sido um período de guerras (Huberman, 1986, p. 7-10).

A partir do século XVI, a classe burguesa emergente passa a adquirir as terras dos senhores e nobres, atingindo diretamente a divisão entre o domínio eminente (ou direto) e o domínio útil, sobre o qual havia se fundado o feudalismo: ora o comprador adquiria ambos os domínios, de uma vez ou por meio de aluguel perpétuo da terra, descaracterizando totalmente a propriedade feudal; ora adquiria apenas o domínio eminente, que frequentemente incluía "o título de nobreza do senhor, o que os colocava em seu lugar no sistema feudal" (Tigar e Levy, 1978, p. 202-203). No entanto, apesar do feudalismo não 
resistiria às tendências reorganizadoras do capitalismo mercantil, nem às forças transformadoras da Revolução Industrial, a nova ordem não inverte as estruturas sociais, apenas abre caminho para uma nova classe dominante. No século XVIII, a propriedade privada como direito fundamental pelo jusnaturalismo liberal - consagrada na Revolução Americana, com seu Bill of Rights $(1776)^{2}$, e na Revolução Francesa (1789), com sua Declaração de Direitos do Homem e do Cidadão $(1789)^{3}$ - garante que possuidores pobres, geralmente excluídos da ordem formal e sem dispor de meios econômicos, além de historicamente expropriados, sejam mantidos à margem da cidadania plena e do gozo deste poder absoluto proprietário do qual decorriam utilidades econômicas básicas para a liberdade e o bem-estar.

Os jurisconsultos napoleônicos não reconheceram à posse o caráter de um instituto jurídico autônomo, [...], talvez até inspirados em Rousseau, que, no capítulo VIII do Contrato Social, assim manifestou: “...o que o homem perde pelo contrato social, é a sua liberdade natural e um direito ilimitado a tudo o que o tenta e que ele pode atingir; o que ele ganha, é a liberdade civil $e$ a propriedade de tudo o que possui. Para não nos enganarmos quanto a estas compensações, é preciso distinguir bem entre a liberdade natural, que só tem por limites as forças do indivíduo, e a liberdade civil, que é limitada pela vontade geral; e entre a possessão, que não é senão o efeito da força ou o direito do primeiro ocupante, e a propriedade, que só pode ser fundada em um título positivo" (grifos meus, Albuquerque, 2002, p. 71).

Assim, fica clara a distinção formalista da propriedade diante da situação fática que é a posse, remetendo-se diretamente a um título positivo, um documento formal, como garantidor deste direito abstrato que é a propriedade. No entanto, mesmo no momento considerado de maior exaltação da propriedade privada pelo Direito Civil - o artigo 544 do Código Napoleônico de 1804 - bem como na passagem destacada de Rousseau, também fica clara a inserção da propriedade em um sistema jurídico no qual

\footnotetext{
${ }^{2} \mathrm{O}$ primeiro parágrafo diz: That all men are by nature equally free and independent, and have certain inherent rights, of which, when they enter into a state of society, they cannot, by any compact, deprive or divest their posterity; namely, the enjoyment of life and liberty, with the means of acquiring and possessing property, and pursuing and obtaining happiness and safety (Comparato, 1998, nota 17).

${ }^{3} \mathrm{Em}$ seu artigo $2^{\circ}$ diz: Le but de toute association politique est la conservation des droits naturels et imprescriptibles de l'homme. Ces droits sont la liberté, la propriété, la sûreté et la résistance à l'oppression (Comparato, 1998, nota 18).
} 
vigoram outros princípios fundamentais como a liberdade. Quando o artigo 544 do referido código estabelece que "a propriedade é o direito de gozar e dispor das coisas da maneira mais absoluta, desde que não se faça em uso proibido pelas leis ou pelos regulamentos" ${ }^{4}$, ele ao mesmo tempo consagra o absolutismo e cria uma ressalva quanto à observância da lei no exercício do direito de propriedade. Tal ressalva, existente desde o direito romano através do axioma jurídico "dominium est jus utendi, fruendi et abutendi re sua quatemus iuris ratio patitu", é a porta de entrada para os institutos que irão, com o tempo, relativizar a propriedade em prol de outros direitos conquistados, como a dignidade da pessoa humana e a moradia.

É neste contexto que o jurista alemão Friedrich Von Savigny (17791861) inicia a discussão acerca da natureza e origem da posse, bem como seu conteúdo, concluindo que a posse era uma detenção qualificada pela aparência e ânimo do possuidor que age como se proprietário fosse, gerando uma série de consequências jurídicas. A proteção da posse, para este autor portanto, seria justificada pela eliminação ou redução da violência, corroborando a situação de fato sustentada como situação de direito proprietário (Albuquerque, 2002, p. 72). Destaca-se, assim, que, para Savigny, o que legitima a tutela da posse é a sua aparência de propriedade criada pelo animus domini, que cria uma situação estável que deveria ser protegida contra ameaça, turbação ou esbulho. Em última instância, a proteção da posse para Savigny é a proteção da própria pessoa contra violência sofrida em sua situação constituída. Para Luiz Edson Fachin (1988, p. 25-26), "o ponto alto da concepção de Savigny é a redução da posse a um mínimo básico de autonomia frente à propriedade, revelando um avanço em relação à concepção então vigente emanada pelo Código napoleônico".

A discussão em torno da posse durante o século XVIII na Alemanha entre juristas romanistas se acirrou quando Rudolf Von Ihering (1818-1892)

\footnotetext{
${ }^{4}$ Art. 544: La propriété est le droit de jouir et disposer des choses de la manière la plus absolue, pourvu qu'on n'en fasse pas un usage prohibé par les lois ou par les règlements.

${ }_{5} \mathrm{O}$ domínio é o direito de usar, fruir e dispor do que é seu, até o ponto em que o permite a razão do direito (FACHIN, 1988, p. 15).
} 
expôs sua teoria objetiva, contrária à de Savigny por subjugar a posse totalmente à propriedade, entendendo sua tutela como legitima apenas quando fosse complementar à proteção proprietária. "[...] Ihering vê na propriedade o fundamento de toda a teoria possessória [...]" (Albuquerque, 2002, p. 73), sendo a posse mera exteriorização da propriedade, sua visibilidade externa. A teoria objetiva, depois de publicada, "fez fortuna" (Fachin, 1988, p. 26):

Jhering viveu no período de transição entre o método históriconatural e o positivismo, predominando, no início, a chamada jurisprudência dos conceitos, e, posteriormente, instaurou-se a fase positivista. Nessa época, o mundo europeu vivia o triunfo do liberalismo, do individualismo e também o início das codificações.

Diante da diversidade de posicionamento dos doutrinadores alemães, o próprio Ihering os organizou em dois grupos: os adeptos à teoria absoluta, que fundamentam a proteção possessória na própria posse, independentemente do direito de propriedade, por haver na posse uma "vontade legítima, que é expressão do direito à liberdade e à personalidade, e "não protegêe-la seria negar a condição de vida às pessoas" (apud Albuquerque, 2002, p. 79), tal como defendida por Georg Friedrich Puchta (1798-1846) e outros; e os adeptos à teoria relativa, que eram mais numerosos e divergentes, mas que partiam da premissa comum que a posse não é concebível por si só senão para servir a outros fins e institutos que não ela mesma. Nesta segunda linha, estão Adolph Rudorff, que legitimava a tutela possessória para eliminar a violência e garantir a paz social, Eduard Gans, para proteger uma 'possível propriedade', entre outros, como o próprio Savigny, para quem esta tutela se deve também à eliminação da violência e à garantia da integridade física do possuidor (Albuquerque, 2002, p. 78).

No entanto, não obstante a famosa e eterna polêmica entre Savigny e Ihering, ou entre a teoria absoluta e a teoria relativa da posse, hoje sabe-se que o momento histórico é determinante na prevalência de uma ou de outra concepção. O positivismo, assim, não sobreviveu às necessidades e mudanças sobrevindas com a $1^{a}$ Guerra Mundial entre 1914 e 1918, e é a partir daí que tanto a teoria objetiva de Ihering quanto o conceito liberal de propriedade vêm 
perdendo espaço para concepções mais humanas referentes ao acesso à terra e aos bens móveis.

\subsection{0 individualismo dobra a esquina: a funcionalização da propriedade e refundação da ordem na solidariedade social}

A teoria objetiva de Ihering, consonante com os interesses dominantes da organização social liberal, influenciou diplomas marcantes no desenvolvimento do Direito mundial, como o código civil alemão, o $B G B$, do início do século XX (1900) ${ }^{6}$, a segunda constituição italiana de $1942^{7}$ e a segunda constituição portuguesa de $1966^{8}$. Em todos estes diplomas, a posse era inicialmente definida como mera exteriorização da propriedade, exercida totalmente em subordinação a esta. No entanto, na medida em que os mesmos diplomas positivam a usucapião ${ }^{9}$, fica claro que reconhecem não apenas o animus domini característico da teoria subjetiva de Savigny, como a própria função social dos institutos.

Ao longo do século XX, o Direito passa a ser influenciado por pensamentos que se distanciavam do jusnaturalismo individualista e liberal, como as filosofias de Auguste Comte e León Duguit. Estes autores, na linha do

\footnotetext{
${ }^{6}$ Segundo Fachin (1988, p. 30-31), o Bürgerliches Gesetzbuch (BGB) teria sido o primeiro a seguir a teoria objetiva, dado ao que dispõe o §854, primeira parte: a posse de uma coisa é adquirida pela obtenção do poder de fato sobre a coisa; e o \$855, se alguém exercer, por outro, o poder de fato sobre uma coisa, na casa ou no negócio deste, ou em uma situação semelhante, em virtude do que tem de prestar obediência às instruções do outro relativamente à coisa, somente o outro é possuidor (Albuquerque, 2002, p. 145). No entanto, o §872 introduz uma exceção à esta noção de posse, que se aproxima do animus domini da teoria de Savigny: quem possui uma coisa como a ele pertencendo é possuidor a título de proprietário, o princípio da usucapião.

${ }^{7}$ Segundo Albuquerque (2002, p. 144), o referido código dispõe, em seu artigo 1.140: a posse é o poder sobre a coisa que se manifesta numa atividade correspondente ao exercício do direito de propriedade ou de outro direito real. Pode-se possuir diretamente ou por meio de outra pessoa, que tenha a detenção da coisa. "[...] também aqui não existe posse que não corresponda ao exercício da propriedade ou de outro direito real, excluindo-se implicitamente a posse dos detentores", mas a doutrina italiana insiste que persistiu o sentido do código anterior em que havia o animus qualificante.

${ }^{8}$ Ainda segundo Albuquerque (2002, p. 145), o referido código português tem disposição análoga à italiana em seu artigo $1.251 \mathrm{c} / \mathrm{c}$ artigo 1.252 , item 1. No entanto, o artigo 1.253 , item $a$, reconhece detentores ou possuidores precários os que exercem o poder de facto sem intenção de agir como beneficiários do direito e, ainda, no artigo 1.290, tais detentores não podiam adquirir por usucapião o que detinham. Com isso, os portugueses apontam para a adoção de ambas as teorias, na medida em que diferenciando esta posse da outra, qualifica a última com o animus domini, inexistente para Ihering.

${ }^{9}$ Os Códigos Civis alemão (1900), italiano (1942) e português (1966) disciplinaram a usucapião, respectivamente, nos $\S 937$ a 945 , no artigo 922 e nos artigos 1.287 ao 1.300 .
} 
próprio movimento keynesiano, partiam de premissas sociais, coletivas e solidárias para destacar não só os direitos naturais e individuais do homem, mas seus deveres como ser humano perante a sociedade. Para eles, "o positivismo não admite nunca senão deveres de todos para com todos; pois que seu ponto de vista sempre social não pode comportar nenhuma noção de direito constantemente fundada na individualidade" (Comte, 2000, p. 284). Assim, a ideia de que o homem nasce livre e dotado de direitos inerentes a essa condição, por si só não se sustenta, entendo os autores que o homem, ao nascer em sociedade é parte dela, e, por isso, é dotado de deveres perante a ela. Uma sociedade, assim, presume solidariedade e interdependência subjacentes, caso contrário, é apenas uma aglomeração de pessoas.

Posto que cada função humana se exerça necessariamente por um órgão individual, sua verdadeira natureza é sempre social; pois que a participação pessoal subordina-se aí constantemente ao concurso indecomponível dos contemporâneos e dos precedentes. Tudo em nós pertence, portanto, à Humanidade: vida, fortuna, talento, instrução, ternura, energia, etc. (Comte, 2000, p. 269).

Para Duguit (1923), a propriedade absoluta e seu status de direito natural precisavam ser descaracterizados como fundamentos da sociedade, que só poderia prosperar e se tornar verdadeiramente produtiva - onde não haveriam áreas sem cultivo, locais urbanos sem construções, casas sem locação, entre outros desperdícios - se refundada na solidariedade e no dever social, em detrimento de sua fundação na propriedade.

O homem vivendo em sociedade tem direitos, mas esses direitos não são prerrogativas que lhe pertencem em sua qualidade de homem. São poderes que lhe pertencem, porque sendo homem social, ele tem um dever a cumprir e deve ter o poder para cumprir esse dever. Vê-se que se está longe da concepção do direito individual. Não são direitos naturais, individuais, imprescritíveis do homem que são o fundamento da regra de direito que se impõe aos homens vivendo em sociedade (Duguit, 1923, p. 12).

Além disso, o autor parte da premissa que apenas os detentores de riqueza poderiam cumprir a tarefa essencial de aumentar a riqueza geral (Duguit, 1923, p. 295), recaindo sobre eles, portanto, um importante dever social decorrente de seu enorme poder como proprietário. Fazendo uma clara distinção entre o direito objetivo - regras de conduta impostas aos indivíduos 
vivendo na sociedade que coletivamente as exigem - e o direito subjetivo poder do indivíduo de obter o reconhecimento social dos seus direitos legitimamente reconhecidos no ordenamento -, Duguit (1923, p. 12-16) conclui que a norma jurídica é sempre social, uma vez que a sociedade e norma social são fatos inseparáveis, produto e produtoras uma da outra.

Segundo este raciocínio, portanto, direitos que geram poderes, geram também deveres, realizando-se a contribuição social dos indivíduos e a manutenção da igualdade formal, uma vez que na sociedade todos têm direitos e deveres diante de todos. A atenção ao fato e à demanda social como forças geradoras do próprio direito foram sintetizadas pelo jurista francês Gaudemet (apud Albuquerque, 2002, p. 9) para quem "a regra do direito é sempre função do fato social'. Nesta perspectiva, a posse, fato social por excelência, deverá fundamentar a regra do direito e terá função social imanente.

A $1^{\mathrm{a}}$ Guerra Mundial - desfeche trágico e tardio para um século de independências e industrialização - ensejou uma onda democrática e solidária no Ocidente. As políticas keynesianas ganhavam espaço em detrimento ao liberalismo de Adam Smith, que havia motivado o crescimento e o enriquecimento das nações europeias e norte-americana agora destruídas pela guerra. As constituições do México (1917) e de Weimar (1919) ilustraram as urgentes preocupações com a pessoa humana, a integridade física e o bem-estar social, desejos dos povos que haviam lutado por independência ou na Grande Guerra. Marco Aurélio Bezerra de Melo (2008, p. 119), destacou:

Na era moderna, mostrou-se marcante a Constituição Mexicana de 1917, que em seu artigo 27, item 3, prescreveu que o Estado pode intervir na propriedade privada para o fim de assegurar a distribuição equânime da riqueza imobiliária ${ }^{10}$. Merece também registro o artigo 153 da Constituição de Weimar de 1919 que positivou: "a propriedade acarreta obrigações. Seu uso deve ser igualmente no interesse geral".

\footnotetext{
${ }^{10}$ Artigo 27, sobre as terras e águas que compõem o território nacional: "La Nación tendrá en todo tiempo el derecho de imponer a la propiedad privada las modalidades que dicte el interés público, así como el de regular, en beneficio social, el aprovechamiento de los elementos naturales susceptibles de apropiación, con objeto de hacer una distribución equitativa de la riqueza pública, cuidar de su conservación, lograr el desarrollo equilibrado del país y el de su conservación, lograr el desarrollo equilibrado del país y el mejoramiento de las condiciones de vida de la población rural y urbana."
} 
Esta última constituição, apesar de sua breve vigência e ambiguidades, exerceu papel fundamental na constituição do Estado social democrata - em seus modelos de welfare state - que se desenhou a partir da crise de 1929 e se consolidou em vários países após ao longo do período entre guerras nazifascista que culminou na $2^{\mathrm{a}}$ Guerra Mundial. Para Jünger Habermas (1997), nascido no início da crise de 1929, a solidariedade e o bem comum são fontes de integração social, prejudicadas pela interpretação liberal dos direitos subjetivos que predominou no século XVIII e XIX, quando houve o rompimento entre o indivíduo sujeito de direito e sua autonomia moral pessoal. O nexo entre direitos e deveres havia se perdido. No fim da $2^{\mathrm{a}}$ Guerra Mundial, o advento da sociologia do direito representou academicamente o desejo de restauração do nexo entre a autonomia privada e a moral pessoal, buscando redescobrir as ligações entre lei e fato, regra e prática, dever-ser e o que realmente somos e fazemos. Assim, a conjuntura fortalece a noção dos direitos subjetivos legitimados apenas quando em consonância com o interesse social ou comum (Albuquerque, 2002, p. 5-6).

Expõe Habermas que, no século XIX, no momento em que o direito em geral perdeu sua fundamentação idealista, especialmente a retaguarda da teoria moral kantiana, o invólucro do 'poder de dominação individual' perdeu o núcleo normativo de uma legítima liberdade de vontade, naturalmente necessitada de proteção (Habermas, 1997, p. 120, apud Albuquerque, p. 6).

É neste momento que uma terceira geração de direitos, além dos individuais e políticos, se incorpora à dignidade humana e à sociedade: os direitos socioeconômicos, que se inseriram nas constituições nacionais e no contexto internacional por meio de tratados das Nações Unidas em 1966. Os Pactos Internacionais sobre Direitos Civis e Políticos e o sobre Direitos Econômicos, Sociais e Culturais, adotados pela Assembleia-Geral da ONU naquele ano, consolidaram uma série de direitos a serem adotados pelos países signatários. No segundo documento mencionado, encontram-se os direitos até então menos protegidos: o direito ao trabalho, à liberdade sindical, à educação, à previdência social e à moradia, entre outros. 
A consagração da função social da propriedade - a já citada função social da posse que lhe é atrelada - tem por objetivo reforçar a proteção do interesse coletivo, a produtividade geral, a distribuição da riqueza e a vontade, dentre as quais o animus domini, de possuir direitos e cumprir deveres para satisfazer necessidades, exercer sua cidadania, desenvolver sua individualidade e contribuir socialmente. Considerando que "o processo histórico de apropriação do homem sobre a terra se desenvolveu de forma artificial" (Fachin, 1988, p. 18), e diante da "constatação de que as condições econômicas e políticas determinaram a origem e o desenvolvimento da propriedade, sob uma forma ou outra" (Fachin, 1988, p. 14), a posse é legitimada como reflexo da realidade social, do caminho que o direito deveria seguir para melhor atender à sociedade.

A introdução da função social no ordenamento gerou um debate entre doutrinadores que a entendiam como sendo uma limitação imposta à propriedade, um princípio junto ao qual a propriedade deve ser ponderada, e aqueles que entendiam ter havido uma reestruturação do conceito de propriedade, que, despida de seus contornos liberais, é reconhecida como propriedade-poder, que não pode ser um direito humano, mas uma fonte de deveres fundamentais, garantindo direitos humanos alheios (Comparato, 1998). Sendo os direitos fundamentais protetores da dignidade da pessoa humana:

a propriedade não se apresenta, concretamente, como uma garantira da liberdade humana, mas, bem ao contrário, serve de instrumento ao exercício de poder sobre outrem, seria rematado absurdo que se lhe reconhecesse o estatuto de direito humano [...] (grifos meus, Comparato, 1998).

Na linha de Comparato (1998), na qual se enquadra o presente trabalho, a função social é um princípio diretivo do ordenamento jurídico, não se dirigindo apenas ao direito de propriedade, e sim se tornando importante fundamento do Estado Social e Democrático de Direito e essencial para a satisfação do bem comum (Albuquerque, 2002, p. 47). Para a citada autora ainda, a função social altera o próprio conteúdo do direito à propriedade ao se consagrar como norma principiológica. Também nesta corrente, defendendo a 
reestruturação conceitual da propriedade pela função social, o professor José Afonso da Silva (1995, p. 241) defende que se

se introduziu princípio novo, além do poder de polícia já existente, é porque o constituinte desejou inserir, na estrutura mesma da concepção e do conceito de propriedade, um elemento de transformação positiva que a ponha a serviço do desenvolvimento social (apud Aguiar, 1996, p. 7).

Para este autor (Silva, 1995), a função social integra a propriedade, incidindo no exercício e na própria atribuição dos poderes do proprietário aquisição, gozo, usufruto, utilização e disposição - sobre seus bens. No entanto, a propriedade, por ainda ser privada, resguarda um conteúdo mínimo essencial, oponível contra o Estado, que é irredutível sem que haja indenização, mas passível de intervenção estatal prevista em lei. Autores como Gustavo Tepedino (1997, 2005 e 2006), Joaquim Castro Aguiar (1996) e Caramuru Antonio Francisco (1991, apud Aguiar, 1996), acompanham este entendimento.

Por outro lado, existem doutrinadores que entendem a função social apenas como uma limitação ou imposição à propriedade, citados neste trabalho apenas para expor o contraponto da corrente aqui adotada, como Orlando Gomes (1996), baseado nos entendimentos do jurista italiano Rodotà, que considera que "função" se contrapõe à "estrutura", e serve para definir a maneira concreta de operar de um instituto. Assim, para Gomes (1996), a função privaria o titular de determinadas faculdades, criaria um conjunto de condições para o titular exercer seus poderes, e o obrigaria a exercer certos direitos elementares do domínio, sem, contudo, alterar sua substância. Neste sentido também posiciona-se Luiz Edson Fachin (1988, p. 17):

A função social relaciona-se com o uso da propriedade, alterando, por conseguinte, alguns aspectos pertinentes a essa relação externa que é o seu exercício. E por uso da propriedade é possível apreender o modo com que são exercitadas as faculdades ou os poderes inerentes ao direito da propriedade.

Vale ressaltar que, nesta discussão, não é motivo de controvérsia a função social da posse, restringindo-se a polêmica à propriedade apenas. Isto provavelmente deve-se ao fato, já apresentado aqui, da posse em si ser uma 
função social, condição que não necessariamente se estende à propriedade. Assim, a propriedade foi reestruturada pela função social que lhe é inerente, mas não a define, na medida em que sua tutela só se estenderá enquanto cumprir esta função social. A propriedade, portanto, não é uma função social, como pode-se argumentar na posse, mas tem uma função social, que cumpre ou deixa de cumprir, definindo sua legitimidade. Esta distinção se erige sobre o exato momento em que a propriedade é inventada - quando nasce da posse mas dela se distingue, tornando-se algo abstrato: sendo ela apenas direito (ou direito-poder), deve-se fazer valer por cumprir sua função, enquanto a posse, por ser um fato social, cumpre em si seu dever.

Com base nos ensinamentos de Gustavo Tepedino (1997, 2005 e 2006), tem-se um binômio entre a propriedade e a liberdade, no qual ambas só se realizam em contextos pluralistas quando atreladas à variedade e à relatividade, na medida em que são acessíveis e compartilhadas de forma equilibrada pela sociedade. Assim, é necessário dirimir a noção de direito real absoluto exercido entre sujeito e objeto, erga omnes, e adotar uma interpretação de propriedade e liberdade com base na relação direta entre sujeito e interesses não proprietários. Diz o Tepedino (2006, p. 158):

Como elemento interno do domínio, a função social é responsável pelo controle de legitimidade funcional do direito de propriedade, impondo ao titular o dever de respeitar situações jurídicas e interesses não-proprietários socialmente tutelados, atingidos pelo exercício dominical.

Para este autor, bem como para Silva (1995), Comparato (1998) e Pietro Perlingieri (2002) e Melo (2008), entre outros, a propriedade que não atender a sua função social perderá suas garantias, judiciais e extrajudiciais, de proteção, por meio da reintegração da posse e de outras faculdades inerentes à propriedade, sendo o interesse proprietário tutelado apenas enquanto atender, também, ao interesse da coletividade. Assim, Melo (2008, p. 120) afirma que o não cumprimento da função social da propriedade por parte do proprietário configura "a perda da tutela da situação proprietária" e "abuso de direito [...] quando a propriedade tenha por objeto bem de produção". Perlingieri (2002, 
p. 229) reforça que "a ausência de atuação da função social, portanto, faz com que falte razão da garantia e do reconhecimento do direito de propriedade".

Ainda, a função social da propriedade logo demandou detalhamento, à fim de que se tornasse eficaz e aplicável, mas para que isso fosse possível, também exigiu especificidade quanto ao âmbito em que se encontravam as várias propriedades: o campo e a cidade. Diante da evolução histórica entre estas duas esferas, as leis relativas ao meio agrário foram produzidas antes, estabelecendo o precedente para as leis urbanas posteriores. Em geral, no meio rural a função social se atrelou, principalmente, ao trabalho, em forma de cultivo, enquanto nas cidades, a função precípua do solo é a moradia, mas devido à variedade de usos dos bens urbanos, o conceito poderá abranger o lazer, o transporte, entre outros direitos. 


\section{CAPÍTULO 2}

\section{Terra e Lei no Brasil: a ambiguidade da legislação fundiária e a construção da questão urbana}

A terra no Brasil é, primeiramente, um recurso tão abundante que representou um grande obstáculo para a colonização do país pelos portugueses. No entanto, ao longo do processo de apropriação e exploração do solo nacional, a terra teve uma distribuição radicalmente irregular, o que foi, e continua sendo, fator determinante na questão urbana. Valorizada desde o século XVI pela Coroa portuguesa, a terra brasileira era fonte de riquezas naturais, como madeira e minério, e tinha condições ideias para a produção agrícola de açúcar e cafés em sistemas de monocultura de base escravocrata. No entanto, a vastidão do território e sua distância da Metrópole, mas, principalmente, as adaptações da letra e da aplicação da lei fundiária lusa à colônia acabaram por ensejar a concentração da terra sob o domínio de alguns senhores.

Assim, mesmo antes da conquista da autonomia jurídica brasileira e da definição de uma política de terras propriamente nacional, já era possível identificar características que marcarão o nosso Direito Fundiário até os dias de hoje: a confusão intencional das leis referentes à posse e à propriedade do solo, as situações e procedimentos jurídico-burocráticas irresolúveis que isto cria, e as soluções extrajudiciais que frequentemente acarretam no curso do processo. Temos, assim, a legalização do ilegal como prática recorrente no Brasil, já que a lei fundiária nunca estabeleceu meios viáveis de resolução de conflitos, nem tampouco o Estado promoveu políticas preventivas para impedi-los de se generalizar.

Do ponto de vista de James Holston (1993), em seu artigo Legalizando o ilegal: propriedade e usurpação no Brasil, a legalização do ilegal, no Brasil, é devida a uma intencional ambiguidade da legislação sobre a terra, que não 
permite a efetivação de institutos previstos e potencialmente transformadores por criar procedimentos irresolúveis ou de difícil cumprimento burocrático.

Em suma, a lei de terra no Brasil promove o conflito, e não soluções, porque estabelece os termos através dos quais a grilagem é legalizada de maneira consistente. É, por isso, um instrumento de desordem calculada, através do qual práticas ilegais produzem lei, e soluções extrajudiciais são introduzidas clandestinamente no processo judicial (grifos meus, Holston, 1993).

Segundo esta tese, a ambiguidade não encontrava-se apenas entre a legislação e as políticas governamentais ou os interesses dominantes, mas no próprio texto legal, que não garantia a efetivação da regularização fundiária nem da distribuição de terras apesar de prevê-las. Ainda, o próprio ordenamento, em suas regulações, muitas vezes contradizia as diretrizes de garantia do acesso à terra e de seu devido aproveitamento, sempre presentes no Direito brasileiro desde a colonização.

Desse modo, encontramos as relações estruturantes entre terra e lei, que sustentam os conflitos, desde o desenvolvimento da política fundiária portuguesa, pensada para ser um instrumento de colonização, até as tentativas imperiais e republicanas de utilizar a reforma da propriedade da terra para trazer imigrantes europeus livres para o Brasil (Holston, 1993).

Partindo desta premissa, argumenta-se neste trabalho que no Brasil, vige até hoje um sistema de posses, especialmente evidente no meio urbano, que se sustenta por meio de leis ambíguas que não garantem seu reconhecimento e regularização. Não obstante os largos avanços conquistados desde a Constituição de 1988, a posse permanece como principal meio de garantia da moradia, que, atrelada ao solo (mesmo que edilício), está sujeita ao seu preço e disponibilidade. Sustenta-se neste trabalho, ainda, que a formação fundiária rural foi determinante para a intensificação da urbanização - a partir da falência da política de fixação do homem no campo e seu consequente êxodo rumo às cidades. Nos centros urbanos, inicialmente sujeitos às mesmas leis agrárias, a população pobre migrante ou ex-escrava encontrou os mesmos problemas de acesso à terra e à moradia que existiam no campo. Sem meios financeiros para garantir a compra e venda de loteamentos legais e ausentes políticas públicas habitacionais, grande parte da população da cidade 
simplesmente ocupou parcela de terra inabitada ou alugou barracos em assentamentos precários e irregulares mantidos por grileiros e/ou proprietários.

Desde a colonização até a promulgação da Lei de Terras de 1850 - que estabeleceu as formas de regularização de títulos e posses diversas - a prática de ocupar a terra e depois pleiteá-la formalmente pelo regime de sesmarias havia se vulgarizado, mas apenas entre poucos. Nem todos os posseiros tinham a possibilidade real de legalizar suas parcelas de terra: era necessário ter poder e exercer influência, o que restringia a formalidade à alguns donatários, capitães, sesmeiros e fazendeiros, que, "explorando essa faculdades, desde o século XVII se legalizaram extensas áreas já ocupadas, das quais se passaram a cobrar foros e arrendamentos de moradores" (Silva, 1996, p. 60 apud Neves, 2001, p. 131). Estas ocupações, espoliações e grilagens promovidas por estes senhores com apoio de suas milícias e conivência do aparato policial e judicial nacional, eram legalmente possibilitadas por outra faculdade de que dispunham: a de definirem os limites de suas próprias propriedades, o que faziam sem indicar "confrontações nem áreas com precisão. Reproduziam vagas referências apresentadas pelos requerentes, conhecedores ou ocupantes dos terrenos pretendidos" (Neves, 2001, p. 131).

O sistema de posses decorrente da confusa colonização por sesmarias e da ausência de lei fundiária entre 1822 e 1850, não encontra legitimação no novo ordenamento nacional. Este capítulo, portanto, irá analisar como a posse, apesar de principal forma de apropriação do solo brasileiro, nunca foi reconhecida como tal, desde o primeiro momento em que é tratada pela legislação brasileira na Lei de Terras de 1850 até sua conceituação mais recente no Código Civil de 2002. Para cumprir o objetivo de recriar a evolução da legislação ao longo da história do país, este capítulo está dividido em três partes: a primeira, que vai da colonização pela Lei de Sesmarias até a autonomia legal brasileira conquistada com o Código Civil de 1916, aborda o surgimento da questão do acesso ao solo na estrutura fundiária do campo; a segunda, partindo da noção de função social incluída na Constituição de 1934, 
discute como este conceito transformou lentamente a perspectiva sobre propriedade e posse no ordenamento brasileiro, consagrando seus avanços na Constituição de 1988; e, finalmente, a terceira parte conclui com as atuais concepções de posse e propriedade e possibilidades de usucapião, a fim de retratar o 'estado da arte' da legislação fundiária brasileira antes do advento da Lei n ${ }^{o} 11.977$ de 2009, tema do terceiro capítulo.

\subsection{A posse e a propriedade na origem da questão da terra brasileira}

No Brasil, a função social da propriedade foi consagrada apenas após a Revolução de '30, marco da transição do eixo agrário-exportador para o urbano-industrial, instaurando no poder os interesses daqueles que buscavam atrair e criar um proletariado urbano que fosse capaz de sustentar o desenvolvimento econômico deste setor. Assim, a terceira Constituição brasileira, promulgada em 1934, determinou em seu artigo 113 , item 17: " $E$ garantido o direito de propriedade, que não poderá ser exercido contra o interesse social ou collectivo, na forma que a lei determinar" (sic, Presidência da República, 2012).

Até então, as duas Constituições que haviam vigorado no Brasil -1824 e 1891 - haviam tratado a propriedade em sua definição liberal ${ }^{11}$, nos moldes, respectivamente, francês e norte-americano. No século XIX, o modelo de Estado constitucionalmente organizado já havia se estabelecido no Ocidente, espalhando-se pelo "Novo Mundo" na medida em que as colônias conquistaram suas independências. No Brasil, com a Independência em 1822, a fase imperial demonstrou forte influência francesa, seja pelo Código Civil

\footnotetext{
${ }^{11} \mathrm{O}$ artigo 179 da primeira Carta Magna do Brasil previa "a inviolabilidade dos Direitos Civil, $e$ Politicos dos Cidadãos Brazileiros, que tem por base a liberdade, a segurança individual, e a propriedade, é garantida pela Constituição do Imperio, pela maneira seguinte" (sic) - e em seu inciso XXII: É garantido o Direito de Propriedade em toda a sua plenitude. Se o bem publico legalmente verificado exigir o uso, e emprego da Propriedade do Cidadão, será elle préviamente indemnisado do valor della. A Lei marcará os casos, em que terá logar esta unica excepção, e dará as regras para se determinar a indemnização (sic, Presidência da República, 2012).
} 
napoleônico de 1804, seja pela Carta promulgada por Luís XVIII em 1814, após a Restauração (Franco, 1981, p. 119).

Os textos constitucionais de 1824 e 1891, que se referem à propriedade de forma análoga ${ }^{12}$, superficial e meramente abstrata, contrastavam com a realidade brasileira da época era um verdadeiro caos fundiário decorrente da suspensão da Lei de Sesmarias de Portugal vigente até a Independência e do fracasso da regularização fundiária proposta pela Lei de Terras de 1850.

A Lei de Sesmarias havia sido criada com o objetivo precípuo de aumentar a produtividade agrícola de Portugal, ameaçando a propriedade dos senhores com o confisco, por um lado, e procurando fixar os camponeses no campo de forma coercitiva, por outro, determinando-lhes as condições de trabalho (Coelho, 1975, p. 233-348 apud Neves, 2001, p. 112).

O objetivo da introdução da Lei de Sesmarias de Portugal era dar uma melhor disciplina ao uso e ocupação do solo, vale dizer, da propriedade imobiliária. Segundo essa lei, todo possuidor de imóvel agricultável estava obrigado a dar sua propriedade ou herdade, um fim social. Se não o fizessem de boa vontade seriam constrangidos a fazê-lo. Deveriam fazer o imóvel produzir trigo, cevada e milho e outras culturas necessárias à subsistência da população. Tudo então ordenado a fazer estava debaixo de prazos rigorosos, cominando-se uma pena àqueles que deixassem de cumprir as ordens reais. As terras que não fossem cultivadas, ou que os seus proprietários se negassem a fazê-lo, para torná-las produtivas, seriam tomadas, confiscadas pela Coroa e dadas a quem as fizesse produzir (Carvalho, 1999, p. 16).

A aplicação desta lei no Brasil ocorreu a partir da repartição da terra e sua doação em forma de capitanias hereditárias por D. João III (1534), com o objetivo de ocupar o novo território. No entanto, as condições que ensejaram a criação desta lei em Portugal não se reproduziam no Brasil recém-descoberto: a preocupação da Coroa era mais a garantia da colonização que a promoção do cultivo, que no Brasil era sustentado pela escravatura e exportado para a metrópole e seus credores. "Assim, o sistema de sesmarias em terras

\footnotetext{
12 A Constituição Republicana, inspirada na norte-americana, consagrou o federalismo e o presidencialismo, mas quanto à propriedade deteve-se em preconizar, em seu artigo 72, §17, que "o direito de propriedade mantém-se em toda a sua plenitude, salva a desapropriação por necessidade ou utilidade pública, mediante indemnização prévia" (Presidência da República, 2012).
} 
brasileiras teria se estabelecido não para resolver a questão do acesso à terra e de seu cultivo, mas para regularizar a própria colonização” (Motta, 2008, p. 121). A intenção portuguesa para sua colônia americana era, portanto, estender e dinamizar suas atividades e negócios comerciais, acumulando riquezas e recursos.

Vasta, distante e predominantemente inabitada, a colônia demandou a adaptação do regime sesmarial - como o aumento das áreas concedidas a um beneficiário e a isenção do pagamento de foros de aluguéis aos colonos e do sesmo original à Coroa - para incentivar o povoamento e a exploração ${ }^{13}$. Inicialmente, a Coroa transferiu para os quinze capitães donatários o poder - e o dever - de doar glebas de terra, chamadas sesmarias, gratuitamente para aqueles interessados em cultivá-la, resguardando para si e sua família apenas uma sesmaria de até 10 léguas ${ }^{14}$. No entanto, as normas estabelecidas pela Metrópole não eram cumpridas na colônia: vastidão e distância, combinadas com o custo elevado para a exploração das terras brasileiras e a ganância dos capitães e sesmeiros, levaram à práticas opostas às regras, como a doação de áreas imensas de uma só vez, para o mesmo colono ou seus familiares, sem controle da sua produtividade ou imposição das referidas normas. Não obstante, em 1590, um Alvará Régio determinava que se dessem "sesmarias a todas as pessoas que, com sua mulher e filhos, deslocassem para qualquer parte do Brasil" (Castro, 1989, p. 94 apud Neves, 2001, p. 124). A Metrópole fazia poucas restrições, desejando que a terra fosse transferida para "pessoa de qualquer qualidade e condição, inclusive estrangeiros que fixassem residência na colônia" (Homem de Carvalho, 1915, p. 8 apud Neves, 2001, p. 124).

Sendo assim, na própria colonização do Brasil haviam duas lógicas contraditórias em ação: de um lado, a promoção do cultivo e da ocupação - a garantia da própria colônia - por capitães, sesmeiros, posseiros e arrendatários

\footnotetext{
${ }^{13}$ Além disso, no Brasil, 'sesmeiro' passou a significar o beneficiário (donatário) da sesmaria, enquanto em Portugal era o agente público encarregado de repartir e distribuir as terras neste regime.

14 Os donatários eram proibidos de doar terras que fossem retornar ao seu domínio, doar terras ao mesmo colono, bem como vendê-las, salvo se aproveitadas durante determinado período de tempo (Neves, 2001, p. 125).
} 
(esses últimos não reconhecidamente) tolerado pela Coroa; de outro, o esforço contínuo de restringir o poder dos capitão e sesmeiros pela realeza portuguesa, que se sentia ameaçada diante do descumprimento deliberado de suas ordens e alvarás e da dimensão do poder que exerciam sobre a terra, os homens e a produção de riquezas. No entanto, os referidos esforços para combater o crescente poder dos capitães e senhores nunca se mostrarão suficientes: na realidade, a Metrópole era dependente dos recursos por eles produzidos e repassados, e, por isso, nunca cumpriu a pena de confisco das terras improdutivas ou a fiscalização das doações para sua melhor distribuição.

As restrições e controles das concessões e conservação das sesmarias não eliminariam seu caráter de latifúndio inacessível ao lavrador sem recursos [...]. Enquanto vigorou no Brasil, esse regime de repartição de terras funcionou como mecanismo de construção e consolidação da estrutura fundiária de grandes propriedades concentradoras de renda, facilitando sua transferência para outros sistemas econômicos, conduta típica das economias primárioexportadoras de origem colonial (Neves, 2001, p. 130).

Ilustrativa desta ambiguidade entre a Lei das Sesmarias adaptada ao Brasil e a prática dos colonos e da própria Metrópole, é uma Provisão Real de 1699 determina "a manutenção das sesmarias antigamente concedidas, por mais vastos que fossem os seus domínios, que estivessem em poder das pessoas que as cultivassem, por si mesmas, ou por foreiros e rendeiros; [...]" (Carvalho, 1999, p. 43-44). A própria Coroa, nesta provisão, sabatina o descumprimento das regras do sistema sesmarial brasileiro, deixando prevalecer neste momento a lógica de promoção do cultivo independentemente da concentração fundiária. No entanto, nesta mesma provisão, já no final do século XVII, a Coroa lusa timidamente reconhece a multiplicidade de sujeitos atuando sobre a terra além dos sesmeiros: foreiros e rendeiros, como citado, posseiros e arrendatários. Os posseiros, por simplesmente ocuparem e cultivarem parcela de terra para sua subsistência, sem pagar pelo seu uso à nenhum senhor nem dispor de qualquer legitimidade juridicamente verificável, terão, a partir deste momento, seus direitos lentamente reconhecidos. 
Os primeiros passos rumo à aceitação jurídica da situação de fato da terra no Brasil - ocupada de forma caótica e permeada de irregularidades cometidas por posseiros, sesmeiros e todos os outros sujeitos derivados de outros acordos - foram dados em meados do século XVII. Resoluções de 1753 já determinavam que "as terras dadas de sesmarias em que houvesse colonos cultivando o solo e pagando foro aos sesmeiros deverias ser dadas [em sesmaria] aos reais cultivadores" (Motta, 2008, p. 123). Em seguida, a promulgação da Lei da Boa Razão em 1769 - que consagra o costume como legítimo e dotado de força de lei - permitiu que se reconhecesse, ainda que em poucas situações fáticas, a legalidade do apossamento (Motta, 2008, p. 123), sem pagamento de foro ou acordo com o proprietário formal e conhecido ${ }^{15}$.

A estrutura fundiária brasileira estabelecida pelo sistema de sesmarias entrara em completa desordem no final do século XVIII. Donatários, arrendatários e posseiros praticavam todo tipo de irregularidade, abusando das caóticas leis circunstanciais, adequadas às condições coloniais, e da falta de legislação específica. Tentando tardiamente retomar o controle da conflituosa situação, há muito perdido, o governo metropolitano, com um Alvará Régio de 5 de outubro de 1795, reafirmou necessidade de não mais se doarem terras já ocupadas, aplicando-se retroativamente essa diretriz em casos de novos e velhos conflitos (grifos meus, Castro, 1989, p. 110-112 e Silva, 1996, p. 65 apud Neves, 2001, p. 134).

A Independência do Brasil em setembro de $1822^{16}$, portanto, foi proclamada em meio a um verdadeiro caos fundiário, em grande parte criado

\footnotetext{
${ }^{15}$ Neste sentido, o Alvará Régio de 5 de outubro de 1795, na tentativa de fortalecer o sistema sesmarial que a Coroa insistia em impor ao Brasil, buscou evitar novos conflitos de terra e, para isso e dentre outras medidas, defendeu o reconhecimento e regularização de cultivadores juridicamente desprotegidos até então: os posseiros, arrendatários, foreiros, rendeiros, etc. Tratando do direito à terra destes, o Alvará dispunha: [...] por uma parte prejuízos e gravíssimos danos aos Direitos da Minha Real Coroa; e por outra parte consequências não menos danosas e ofensivas do Público Benefício, $e$ da igualdade, com que devem, e deviam ser em todo o tempo distribuídas aos mesmas terras pelos seus Moradores, chegando a estado tal esta irregular distribuição, que muitos desses Moradores não lhes tem sido possível conseguirem as sobreditas Sesmarias, por Mercê Minha, ou dos Governadores, $e$ Capitães Gerais do dito Estado, à força de objeções opostas por quem sem algum Direito não deviam impugná-las; outros pelo contrário as tem compreendido, e apreendem, e delas se apossam sem Mercê, e sem licenças legítimas, que devem ter para validarem os Títulos de suas possessões (grifos meus, Motta, 2008, p. 124). Neste espírito, a Coroa atendia à pedidos e solicitações de posseiros em busca de proteção e conservação de suas posses, como os exemplos contidos em Motta (2008, p. 124126): em Pernambuco em 1821 e na Vila São João Príncipe em 1822.

16 À beira da Independência, a situação fundiária brasileira era complexa e ambígua, havendo um incipiente reconhecimento do direito à posse, já com fins de regularizá-la em propriedade, no contexto de um Brasil agrário e latifundiário. Comuns eram as espoliações de populações nativas e posseiros
} 
para atender os interesses de sesmeiros que aumentavam suas terras e rendas, "indicando demarcações vagas e imprecisas, contando com a conivência de prepostos governamentais que não fiscalizavam e que, quando cobrados, deixavam-se subornar, criando uma tradição que se arraigaria na cultura burocrática brasileira" (Neves, 2001, p. 135). Ainda, soma-se à isso a já referida multiplicidades de apropriações da terra, como invasões, loteamentos, vendas e apossamentos diversos, e os aludidos conflitos derivados desta sobreposição descontrolada de posses e titularidades. Com a independência, suspenderam-se as concessões de sesmarias e o próprio fim do regime era palpável, uma vez que constatou-se sua incapacidade de regrar e pacificar a questão fundiária brasileira. Era o início do Direito Fundiário pátrio, autônomo das leis portuguesas e dos interesses metropolitanos.

Logo, enquanto em Portugal, o controle do regime jurídico das sesmarias foi mantido sobre pequenas glebas e sustentado com assalariamento do trabalhador do campo, no Brasil, a vastidão territorial e a escravidão diluíram este regime, transformando-o numa fachada legal sobre a qual foi erigido todo o sistema fundiário - propriedade, posse e uso do solo - desde a colonização até a primeira lei propriamente fundiária brasileira, em 1850. No campo, as consequências da falência desta política foi a criação de latifúndios, que - na medida em que se alforriavam os escravos no final do século XIX e mantinham menos trabalhadores assalariados, muitas vezes migrantes europeus - deram impulso ao êxodo populacional em direção aos centros urbanos, onde a terra também passou a se reestruturar.

O projeto de lei que se tornou a Lei de Terras $n^{\circ} 601$ de 1850 e sua regulamentação (Decreto $\mathrm{n}^{\circ} 1.318$ de 1854), envolveu, principalmente, três pontos nodais: (i) a regularização da ocupação e propriedade fundiária, numa espécie de 'acerto com o passado'; (ii) a definição dos procedimentos estatais referentes à venda de terras devolutas e à cobrança de impostos territoriais e/ou

pobres por senhores (sesmeiros e donatários) influentes junto aos poderes públicos colonial e metropolitano e comandantes de milícias pessoais, que, diante da legislação português que ignorava a existência destes nativos e posseiros, eventualmente tinham seus direitos reconhecidos sobre as terras espoliadas (Neves, 2001, p. 131). 
imobiliários; (iii) a promoção da colonização por meio de atração de estrangeiros, "imigração de trabalhadores pobres em razão da insuficiência de trabalho escravo proveniente da cessação do tráfico de africanos" (Motta, 2008, p. 131). Para realizar o primeiro ponto apresentado, o projeto buscou abranger todas as situações fundiárias - sujeitos e formas de aquisição da terra - existentes, como ilustrado a seguir.

A primeira seria a revalidação das terras das sesmarias caídas em
comisso, sem posseiros; a segunda seria a revalidação das terras
caídas em comisso, com posseiros, mas com terras suficientes para
serem distribuídas entre os posseiros, ficando o restante excedente
para os sesmeiros. A terceira situação era a revalidação de sesmarias
caídas em comisso, com vários posseiros, entre eles os próprios
sesmeiros, desde que havendo terras suficiente para todos. A última
possibilidade seria as sesmarias caídas em comisso totalmente
ocupadas por posseiro, mas não sendo o sesmeiro um dos posseiros,
tendo o direito à terra apenas aqueles posseiros (Motta, 2008, p.
137).

No entanto, o texto do projeto recebeu interpretações diversas e por vezes opostas na Câmara dos Deputados e no Senado: uns pensavam que a revalidação das sesmarias reativava antigos privilégios e colocava o sesmeiro em vantagem diante dos posseiros, outros achavam que o projeto extrapolava os limites razoáveis em prol dos posseiros, estando o direito dos sesmeiros em comisso submetidos ao direito de posse daqueles que cultivaram a terra sem título. A discussão mais calorosa se deu, assim, em torno dos direitos de posseiros e sesmeiros, um em detrimento do outro. Enquanto o direito de posse estava fundamentado na exploração do solo pelo cultivo, em consonância, inclusive, com a filosofia de alguns liberais como John Locke, para quem a propriedade era legitimada pelo trabalho, os direitos do segundo sujeito estavam sustentados em títulos.

$\mathrm{Na}$ visão formalista e excludente, que negava o direito à posse, rechaçava-se o apossamento que é, em retrospecto, a própria origem da propriedade: "qualquer indivíduo faz-se acompanhar por três escravos, entra por um terreno, roça uma porção de mato, planta uma pouca de mandioca e diz - Isto é meu" (Motta, 2008, p. 139). Contraditando o direito dos posseiros e a consagração do cultivo como legitimação da ocupação, as pretensões de 
"impedir que todos se apossassem das terras devolutas", na lógica de que "somente com a defesa das terras devolutas se poderia achar trabalhadores livres dispostos a cultivar os 'nossos terrenos '”, a Lei de Terras consagrou, em seu artigo $1^{\circ}$ a compra e venda e a sucessão hereditária e, em seus efeitos, a garantia proprietária apenas para os senhores com títulos e para o Estado, das terras devolutas, que seriam importante fonte de receita (Motta, 2008, p. 140).

Sua versão final denuncia a dificuldade em estabelecer mecanismos eficazes de regularizar o acesso à terra. A ambiguidade presente em seus artigos revela os conflitos existentes à época de sua votação e expressa percepções diversas sobre os diferentes costumes e concepções em relação ao acesso à terra (Motta, 2008, p. 141).

Grande parte dos posseiros eram os grandes fazendeiros que receberam por doação as sesmarias e expandiram seus limites pelo apossamento, ou que compraram ou grilaram grandes parcelas de terra, mas a lei possibilitou que um também grande número de pequenos e/ou pobres posseiros garantissem suas posses. Afirma Marco Aurélio Bezerra de Melo (2008, p. 148), em trabalho especificamente sobre a legitimação de posse, que na Lei de Terras este instrumento era bastante limitado, uma vez que sua conversão em propriedade da terra só poderia ocorrer pela compra, conforme interpretação com do referido artigo $1^{\circ}$. Assim, a diferença estruturante era a de que os grandes fazendeiros, dispondo de títulos muitas vezes forjados de suas terras, seriam consagrados como proprietários por esta lei, enquanto os posseiros, legitimados, apenas se manteriam como tal ${ }^{17}$.

A regulamentação da Lei de Terras previa a forma pela qual a terra era para ser demarcada e registrada, disciplinando os Registros Paroquiais da Terra - os primeiros registros fundiários nacionais - que eram mantidos pelos vigários em organização provincial. $\mathrm{O}$ período estabelecido para os registros das propriedades, entre 1854 e 1857 , se provou insuficiente para atrair a maioria dos sesmeiros e posseiros de todo tipo, cuja decisão de atender às determinações legais estava condicionada pela tradição de descumprimento de

\footnotetext{
${ }^{17}$ Mesmo assim, a corrente política que pretendia ajudá-los, procurou solucionar o problema da onerosidade das exigências para a legitimação das posses em 1858, determinando-se a primeira forma de gratuidade de justiça no Brasil (Motta, 2002, p. 142-143).
} 
regras de medição e controle fundiário e pela incerteza se registrar suas terras lhes seria vantajoso ou não. Para os senhores de terra poderosos, é possível que registrar as terras pudesse significar limitar seu poder e submeter-se ao governo.

$\mathrm{O}$ otimismo era devido à crença no sucesso e operacionalidade de um sistema de propriedades baseado em registros de iniciativa dos sesmeiros e posseiros e contendo apenas informações por eles oferecidas. "Estes registros os chamados Registros Paroquiais de Terra - tornaram-se obrigatórios para 'todos os possuidores de terras, qualquer que seja o título de sua propriedade e possessão" (Motta, 2008, p. 161). No entanto, na medida em que se tornaram obrigatórios, também foi constatada a sua fragilidade: "o relator, no entanto, estava ciente de que muitas das informações dos senhores de terras não eram apenas incompletas, mas também estavam longe de ser verdadeiras" (Motta, 2008, p. 163)

Neste contexto, havia um baixo número de terras registradas, mas, simultaneamente, muitas províncias - nos quais Motta destaca a do Rio de Janeiro - forjavam a inexistência de terras devolutas em seus municípios, à fim de sustentar o status quo local, impedindo que o Estado regulasse as fronteiras das fazendas e vendesse parcelas de terras limítrofes à outros. Além disso, " $a$ obrigatoriedade de registrar uma parcela de terra não vinha acompanhada de qualquer exigência quanto à prova documental ou testemunhal em relação à área efetivamente ocupada" (Motta, 2008, p. 167). Isso permitia que os registros, assim como as antigas cartas de doações de sesmarias, fossem vagos e imprecisos. A própria lei possibilitava isso, uma vez que não era exigida a precisa delimitação da propriedade e os confrontantes também eram apontados pelo próprio possuidor, mas muitas vezes, no entanto, não se reconheciam mutuamente. "O tratamento técnico do registro de terras é muito problemático, em razão da multiplicidade das informações ali presentes" (Motta, 2008, p. 167). Diante deste quadro, logo ficou claro que os registros dificilmente poriam fim aos litígios de terra. 
A eficácia dos registros paroquiais ainda era diminuída pelo fato de, entre posseiros e sesmeiros caídos em comisso, estes não equivaliam a títulos de propriedade. Por isso, "o ato de registrar a terra não representava, de imediato, a consagração e legitimação do domínio sobre as mesmas, ou seja, o reconhecimento automático por aqueles que eram ou deveriam ser os seus confrontantes" (Motta, 2008, p. 171). Isto também pode ter servido de desincentivo na demanda por registros.

Registrar ou não sua terra, contar ou não com o reconhecimento de seus confrontantes, era, em suma, uma questão difícil e estava relacionada à existência ou não de uma teia de relações pessoais já consolidada, capaz de legitimar os limites territoriais declarados (Motta, 2008, p. 177-178).

Sendo assim, a Lei de Terras e sua regulamentação não foram suficientes para regularizar a situação fundiária brasileira, sendo esta inoperância causada por uma série de motivos que envolviam desde a vastidão territorial do Brasil até o poder e a influência dos grandes fazendeiros, passando pela construção de uma tradição de posse que nunca logrou reconhecimento jurídico e pela ineficiência dos registros paroquiais. Este insucesso, ao longo do século XIX, levou o Brasil agrário à sofrer transformações estruturantes que, culminando com a abolição da escravatura (1888) e a proclamação da República (1889), desencadeou grandes migrações rumo aos centros urbanos e o início da industrialização do Sudeste do país ${ }^{18}$.

\footnotetext{
${ }^{18} \mathrm{O}$ custo da mão-de-obra na zona rural é determinante no custo da mesma na zona urbana. A baixa remuneração na zona agrícola faz com que haja um crescente êxodo para as cidades, formando-se uma abundância de mão-de-obra não especializada em oferta na zona urbana e, consequentemente, barata, o que transfere o poder de compra a grupos sociais e rendas mais altas, assegurando, assim, a continuidade da expansão do mercado. Em síntese, nos diz Celso Furtado, a modernização da agricultura produtora de gênero de primeira necessidade não seria factível sem modificações amplas no padrão de distribuição de renda. A estrutura agrária, ao canalizar os investimentos para setores privilegiados e assegurar a reprodução da mão-de-obra ao mais baixo custo possível, cria as condições para que se maximize o excedente a ser utilizado nas zonas urbana (Araújo, 1985, p. 28-29, grifos meus).
} 


\subsection{Do campo à cidade: a exclusão da posse como meio de acesso ao solo e seus desdobramentos}

O fracasso da reestruturação do campo brasileiro é, em parte, devido à inoperância da Lei de Terras de 1850 em registrar as posses e propriedades segundo sua lógica privatista, na qual as terras particulares deveriam ser devidamente demarcadas por iniciativa dos próprios posseiros e sesmeiros, para, só então, definirem-se as terras públicas e devolutas. Pedidos de levantamento das terras devolutas - reiterados nos anos de 1860, 1865 e 1885 permaneceram infrutíferos apesar do novo regulamento, demonstrando a ineficiência dos registros paroquiais, diante dos quais as Províncias declararam reiteradamente não dispor de terras devolutas ou improdutivas (Motta, 2002, p. 162-263). Além disso, a interpretação geral da lei não era favorável aos posseiros, como ilustra o Acórdão de 1907, que interpretou a Lei n ${ }^{\circ} 601$ :

os posseiros de terras [...] não tinham a propriedade dessas terras,
eram simples posseiros como a lei os chamava; o laço jurídico que
os prendia à terra era, unicamente, a posse. As Lei 601, preferiu
adotar um regime de Transação, pelo qual se comprometeu a
reconhecer o direito de todos os posseiros que, nos prazos dados,
legitimassem suas posses (apud Motta, 2002, p.19).

Pouco depois, a República Velha produziu o primeiro Código Civil brasileiro em 1916, que, como a conjuntura que o promulgou, estava voltado para os interesses agrários protegidos pela conceituação tradicional e conservadora da propriedade. Ignorando o sistema de posses que vigia apesar das tentativas frustradas de registro e regularização da Lei de Terras de 1850 e o processo de urbanização que se iniciava no litoral, o Código Civil de 1916 permitiu que ambos se desenrolassem sem planejamento ou fiscalização.

Em termos jurídicos, e segundo Clóvis Beviláqua, "o Código Civil brasileiro foi o primeiro a consagrar, inteira e francamente, a doutrina de Jhering sobre a posse" (apud Fachin, 1988, p. 31), dispondo o artigo 485 que "considera-se possuidor todo aquele, que tem de fato o exercício, pleno, ou não, de algum dos poderes inerentes ao domínio, ou propriedade". Tal conteúdo seria reproduzido, ainda, nos já citados Códigos Civis italiano e 
português deste século. Mas assim como apontamos sobre estes, o Código Civil brasileiro, ao disciplinar a usucapião em seu artigo 530, demonstra a adoção, mesmo que pontualmente, da teoria subjetiva que reconhece o animus domini como qualificante da posse para a aquisição da propriedade. Assim, no nosso Código, a usucapião é, ao lado da transcrição do título de transferência no registro de imóveis - seja por compra e venda, doação ou outro negócio alienante -, da acessão e do direito hereditário, uma das formas legítimas de aquisição da propriedade. Desta forma, a aquisição ocorria mediante propositura de ação judicial, à fim de obter sentença declaratória da consumação da usucapião, cujo outro efeito é ser constitutiva de título a ser registrado no devido registro de imóveis.

Inicialmente, o prazo previsto no Código Civil (1916) para a usucapião adquirida sem justo título - extraordinária - por posse ininterrupta e sem oposição, era de 30 anos, a partir dos quais se poderia pleitear o reconhecimento do domínio junto ao Poder Judiciário (artigo 550). Caso o possuidor detivesse título de boa fé - usucapião ordinária - adquiriria a propriedade em 10 anos se estivesse presente, morando no mesmo município da terra, e em 20 anos se estivesse ausente, habitando município diverso (artigo 551). Neste artigo, o Código reforça sua inspiração em um Brasil agrário, na medida em que, prevendo a possibilidade de alguém usucapir bem imóvel habitando local diverso, legitimava a usucapião pelo cultivo e não pela moradia.

Apesar desta ressalva, o Código Civil de 1916 previu a propriedade privada de forma classicamente liberal, sendo plena quando o proprietário reúne sob seu domínio os direitos de usar, gozar e dispor de seus bens e de reavê-los do poder de quem quer que injustamente os possua (artigos 524 e 525). Ademais, o artigo 527 determina que "o domínio presume-se exclusivo e ilimitado, até prova em contrário", fortalecendo a presunção em favor do proprietário em detrimento, inclusive, do próprio Estado. Isso indica que o diploma ainda era adepto ao paradigma positivista, sem contestar a 
conceituação de propriedade tradicional e dominante até então. Interessante contrastar este com diplomas do mesmo período, como as já citadas Constituições Mexicana de 1917 e Weimar de 1919, que reconheciam pioneiramente a função social da propriedade no contexto moderno. " $E$ um código, portanto - apesar da excelência técnica com que foi elaborado e da triagem formal [...] - voltado para o passado, destinado a reger as relações jurídicas em um Brasil rural" (LIRA, 1997, p. 332).

Assim, a função social apenas surge no ordenamento brasileiro com o advento dos processos de industrialização e urbanização, sobretudo do Sudeste do país. A Constituição de 1934, neste espírito de funcionalização da propriedade - submetida ao interesse social e coletivo por não poder ser exercida contra este - eleva à status constitucional a usucapião, em seu artigo 125:

Todo brasileiro que, não sendo proprietário rural ou urbano, ocupar, por dez anos contínuos, sem oposição nem reconhecimento de domínio alheio, um trecho de terra até dez hectares, tornando-o produtivo por seu trabalho e tendo nele sua morada, adquirirá o domínio do solo, mediante sentença declaratória devidamente transcrita (Presidência da República, 2012).

Assim, a Constituição de 1934 cria uma nova espécie de usucapião, a especial, por atrelar à esta novas condições não exigidas no Código de 1916 - o limite máximo de 10 hectares e a produtividade pelo trabalho ou a moradia em troca da diminuição do prazo para dez anos. Este novo instituto depois se transformará na usucapião especial urbana, tratada logo a seguir. Ainda sobre a Carta de '34, vale ressaltar que esta já buscava abarcar as especificidades que surgiam com a diferenciação do meio rural, do meio urbano, disciplinando, no artigo 121, o trabalho assalariado que crescia nas cidades, e, no $\S 4^{\circ}$, determinava:

O trabalho agrícola será objeto de regulamentação especial, em que se atenderá, quanto possível, ao disposto neste artigo. Procurar-se-á fixar o homem no campo, cuidar da sua educação rural, e assegurar ao trabalhador nacional a preferência na colonização e aproveitamento das terras públicas (Presidência da República, 2012). 
Apesar de não detalhar, é claro que a referida política de fixação do homem no campo só poderia ocorrer por meio da garantia de um salário suficiente para a manutenção do bem-estar ou pela facilitação do acesso à terra. No entanto, a Constituição de 1934 teve vida curta, e, logo após sua promulgação, Getúlio Vargas instaurou o regime do Estado Novo, sabatinandoo com uma nova Constituição em $1937^{19}$. Neste diploma, a usucapião especial se manteve igual à Carta anterior, no artigo 148, mas a nova Carta retira de seu texto a política de fixação do homem no campo, possivelmente indicando uma falta de importância ou de compromisso com a ideia. O Estado Novo, desta forma, deixou intacta a estrutura fundiária rural brasileiro, mantendo as relações de trabalho e a inacessibilidade à terra no campo e incrementando o fluxo migratório para os centros urbanos.

O primeiro período formalmente democrático do país, inaugurado com a Constituição de 1946, previu em seu artigo 147, como princípio do ordenamento econômico e social nacional, que: "o uso da propriedade será condicionado ao bem-estar social. A lei poderá [...] promover a justa distribuição da propriedade, com igual oportunidade para todos" (Presidência da República, 2012). Ainda, trouxe de volta a política de fixação do homem no campo, desta vez no artigo 156, voltadas especialmente para habitantes nacionais em situação de pobreza ou desemprego. Neste mesmo artigo, a Constituição define que os Estados federados deverão assegurar aos posseiros de terras devolutas a preferência na venda, consagrando, como o fez a Lei de Terras de 1850, a compra e venda e não a posse como forma de aquisição destas terras, mesmo reconhecendo que já haviam posseiros nelas. O limite para esta aquisição, bem como para a usucapião especial ( $\$ 3^{\circ}$ do art. 156), aumentou - em relação à Constituição de 1934 - de dez para vinte e cinco hectares.

\footnotetext{
${ }^{19} \mathrm{O}$ espírito autoritário se refletiu com a retirada do termo interesses sociais e coletivos do artigo 122, item 14, que garante: o direito de propriedade, salvo a desapropriação por necessidade ou utilidade pública, mediante indenização prévia. O seu conteúdo e os seus limites serão os definidos nas leis que the regularam o exercício (Presidência da República, 2012).
} 
Mantida a estrutura fundiária no campo brasileiro, o contexto por detrás do novo período de democracia era o de plena urbanização e êxodo rural - as cidades como o Rio de Janeiro, capital do país até 1950, recebiam milhares de migrantes pobres do interior do Estado e de outras regiões, sem, contudo, dispor dos meios jurídicos ou da atenção política necessários para absorvê-los. Desde o início do século, portanto, se criou uma maneira de morar não formal, mas a única possível: a ocupação, ou, como preferem alguns, as invasões (Cotta, 2011, p. 11.834). Na década de '40, porém, surgem as primeiras tentativas de promover políticas públicas habitacionais, mas estas logo se mostraram insuficientes e/ou incapazes de reverterem, ou mesmo de aliviarem, o déficit de moradia que havia criado, em centros urbanos como o Rio de Janeiro, São Paulo e Recife, assentamentos irregulares, ocupações e favelas.

O período de democracia dura até 1964, quando diversas tensões sociais em torno do trabalho e da terra, especialmente a tendência esquerdista que parecia dominar o Governo e suas promessas referentes ao salário mínimo e à reforma agrária, levam ao golpe militar. A década de 1960 - momento em que se tornou claro as estreitas ligações entre a estrutura fundiária, o baixo assalariamento no campo e o êxodo rural - é exatamente o momento em que a população urbana alcança a população rural, estando praticamente metade dos 70 milhões de brasileiros da época nas cidades (IBGE, 2012). Diante deste quadro, o Brasil passou a enfrentar outra preocupação, que se assemelhava à que levou os portugueses a criarem a Lei de Sesmarias no século XIV: a baixa produtividade agrícola diante do potencial do país e da demanda da população.

Segundo a Mensagem no 33 de 1964, assinada pelo Marechal Castelo Branco, o principal objetivo do Estatuto seria reverter o processo de êxodo, dando reais possibilidades para a já referida política de fixação do homem no campo, na medida em que haviam "legiões de assalariados, parceiros, arrendatários, ocupantes e posseiros que não vislumbram, nas condições atualmente vigentes no meio rural, qualquer perspectiva de se tornarem proprietários da terra que cultivam" (apud Lira, 1997, p. 325). 
Impossibilitado de ter acesso a terra própria, além da produtividade reduzida, o trabalhador rural não cria para si condições de melhoria de padrão de vida. Não introduz práticas novas, não absorve qualquer técnica tendente a aumentar a produtividade. Sem possuir terra não pode exigir a concessão de facilidades creditícias da assistência técnica, da mecanização, do aperfeiçoamento do sistema de escoamento dos produtos agrícolas. A experiência universal mostra que a modificação da estrutura agrária dos países que realizaram reformas agrárias bem-sucedidas cria condições novas para o trabalho rural e força a modificação dos sistemas creditícios, assistencial e de mecanização (apud Lira, 1997, p. 325-326).

Para este trabalho, não interesse pormenorizar o Estatuto da Terra de 1964, apesar dos avanços legislativos que este trouxe ao ordenamento, por dois motivos principais: primeiro, porque o enfoque desta monografia é o meio urbano e, segundo, por não ter sido este Estatuto muito aplicado na prática. Dele, vale ressaltar apenas a contradição que passou a existir entre a política agrária que a lei estabeleceu e a prática autoritária e internacionalista do governo. Assim, apesar da definição detalhada de função social ${ }^{20}$ da propriedade e da previsão de proatividade estatal para garanti-la ${ }^{21}$, o Estatuto da Terra não gerou os efeitos pretendidos, tanto pela extensão das mudanças que seu texto permitia, quanto pela falta de interesse político e econômico da época nessas mesmas mudanças.

O fato é que, apesar de promulgarem uma política avançada para a reforma agrária - criando novas condições e meios jurídicos para a desapropriação de terras entre outros mecanismos legais - os mesmo governantes militares promoviam políticas de ocupação e produção nas regiões Centro-Oeste e Norte do país que davam volumosos subsídios a grandes empresas,

\footnotetext{
${ }^{20}$ Art. $2^{\circ}$ É assegurada a todos a oportunidade de acesso à propriedade da terra, condicionada pela sua função social, na forma prevista nesta Lei.

$\S 1^{\circ}$ A propriedade da terra desempenha integralmente a sua função social quando, simultaneamente: a) favorece o bem-estar dos proprietários e dos trabalhadores que nela labutam, assim como de suas famílias; b) mantém níveis satisfatórios de produtividade; c) assegura a conservação dos recursos naturais; d) observa as disposições legais que regulam as justas relações de trabalho entre os que a possuem e a cultivem.

[...]

Art. 12 À propriedade privada da terra cabe intrinsecamente uma função social e seu uso é condicionado ao bem-estar coletivo previsto na Constituição Federal e caracterizado nesta Lei. (Estatuto da Terra de 1964, Presidência da República, 2012).

${ }^{21}$ Artigo 13: [...] o Poder Público promoverá a gradativa extinção das formas de ocupação e exploração da terra que contrariem sua função social (Estatuto da Terra de 1964, Presidência da República, 2012).
} 
que passaram a comprar imensos tratos de terra, expulsando, com o uso da força, milhares de posseiros, que engrossavam o contingente dos 'sem terra', agravando substancialmente a questão agrária nacional, e aumentando significativamente os conflitos decorrentes da luta pela posse da terra (Lira, 1997, p. 328).

Assim, reporta-se à tradição legislativa brasileira de ambiguidade, que permitia que houvesse uma verdadeira teia de posses e composses sob o sistema formal proprietário, sem que as regras firmadas para a regularização e democratização da terra se fizessem valer. Vale ressaltar aqui que a partir da legislação, a atuação do Governo e o entendimento do Judiciário foram, e são, determinantes para configuração fundiária. Neste sentido, sobressai a relação mantida com o Judiciário, que uma vez provocado não pode abster-se de decidir, sendo suas interpretações da lei fundamentais para a efetivação da regularização por institutos como a usucapião, adjudicação compulsória, legitimação da posse, entre outros.

Deste ponto de vista, a eficácia da legislação pode ser medida a partir de seu desempenho nos tribunais, seja direcionando as decisões com princípios e definições, seja regrando direitos e os procedimentos para garanti-los. No meio rural, as proporções continentais do país podem servir como justificativa para o fracasso da regularização fundiária, juntamente com as relações de poder locais capazes de evitá-la. Por sua vez, no meio urbano a ocupação e a posse de parcelas do solo para a moradia, que demanda a edificação de uma casa, pressupõe maior visibilidade devido à concentração espacial e à densidade populacional. Igualmente visível foi, então, quando a política prevista para regularização das cidades não conseguiu sequer impedir o crescimento dos assentamentos e ocupações irregulares em todos os centros urbanos do país.

Fruto da mesma conjuntura militar, a Constituição de 1967, mantida neste ponto pela Emenda de 1969, inaugurou o uso da expressão "função social" no texto constitucional, mas manteve-a dentre os princípios da ordem econômica e social. Diz o artigo 157: “a ordem econômica tem por fim realizar a justiça social, com base nos seguintes princípios: [...] III - a função social da propriedade". Paralelamente, são excluídos desse diploma as usucapiões 
especiais antes constitucionalmente consagradas. Ambas os diplomas são considerados como eminentemente instrumentais por Afonso Arinos de Melo Franco (1981, p. 132-134), que afirmou ter continuado o projeto militar de nação independentemente destes dispositivos, comprometendo a concretização da função social e das reformas previstas em seus diplomas legais.

A produção legislativa militar não parou na questão rural: em 1979, o governo promulgou a Lei de Parcelamento do Solo Urbano (Lei ${ }^{\circ}$ 6.766). Em termos de regulamentação da posse e propriedade, os militares ainda regraram a usucapião especial rural, diferenciando o instituto por espécie pela primeira vez no ordenamento pátrio. A curta Lei ${ }^{\circ} 6.969$ de dezembro de 1981 determina prazo inédito de apenas cinco anos para a usucapião de área rural contínua, não excedendo 25 hectares, cultivada e habitada por possuidor. No entanto, a lei traz inovações procedimentais que permaneceram negligenciadas diante das possibilidades que criou: a restrição da usucapião à terras privadas e devolutas (artigo $2^{\circ}$ ), o procedimento sumaríssimo para a ação que a declara (artigo $5^{\circ}$ ), a gratuidade de justiça assegurada inclusive para o Registro de Imóveis (artigo $6^{\circ}$ ), entre outras. Destaca-se a possibilidade da usucapião especial ser reconhecida administrativamente quando em terras devolutas (artigo $4^{\circ}, \S 2^{\circ}$ ), antecedendo ao processo de desjudicialização que é será analisado no item 4.1 deste trabalho. Por fim, a lei, admitindo as circunstâncias muitas violentas das relações sobre a terra no campo, assegura em seu artigo $9^{\circ}$ a possibilidade do autor pleitear ao juiz a presença da autoridade policial para garantir sua permanência no imóvel e a integridade física de seus ocupantes.

O crescimento populacional, mesmo o intencionado pela colonização, naturalmente demandou o parcelamento de grandes fazendas em chácaras, e lotes, nas imediações dos núcleos urbanos em formação. Desde a Lei de Terras de 1850 , esta atividade de desmembramento do solo para viabilizar a fixação do homem agora na cidade, era feita mediante compra e venda ou arrendamento, cobrando-se aluguel sem transferir o domínio. Portanto, só incluía aqueles capazes de cumprir com esta exigência, sem permitir que os 
posseiros, ou os "invasores", tivessem suas moradias autoconstruídas legitimadas por si só. Os dispositivos da Lei de Terras, voltados ao contexto rural, tinham pouca aplicabilidade no meio urbano, não servindo às suas especificidades, que, se já numerosas no campo, se faziam ainda mais multifacetadas na cidade.

A legislação brasileira só alcançou o processo de urbanização iniciado no início do século trinta anos depois, por meio do Decreto-lei $\mathrm{n}^{\mathrm{o}} 58$ de dezembro de 1937, publicado na Era Vargas. Antecedente legislativo da Lei de Parcelamento do Solo Urbano, este decreto regulamentou o loteamento e a venda de terrenos para pagamentos em prestações, sem diferenciar entre meios urbano e rural.

Curto, deste texto legal, ressalta-se a cobrança, como condição para o loteamento, de apresentação de relação cronológica dos títulos de domínio, desde 30 anos, com indicação da natureza e data de cada um, e do número e data das transcrições, ou cópia autêntica dos títulos e prova de que se acham devidamente transcritos (artigo $1^{\circ}$, I, item b da lei, Presidência da República, 2012), buscando prevenir que ocorressem loteamentos irregulares e grilagens. Ainda, cobrava-se do proprietário para o loteamento de terras privadas, o registro e cartório de Registro de Imóveis: (I) um memorial incluindo o plano de loteamento, de que conste o programa de desenvolvimento urbano, ou de aproveitamento industrial ou agrícola [...]; (II) a planta do imóvel indicando medição e loteamento com dimensões e numerações, os espaços livres, vias de acesso e vias públicas, entre outras características, assinada por um engenheiro; (III) um exemplar de caderneta ou do contrato-tipo de compromisso de venda dos lotes; entre outras certidões.

Além disso, o Decreto-lei n58/1937 criou a adjudicação compulsória, permitiu que o contrato de promessa de compra e venda fosse por instrumento particular, exigindo firmas reconhecidas por tabelião. Sendo assim, o restante do Decreto estabelecia o trâmite que o exercício jurisdicional deveria seguir. Tal regulamentação, portanto, restringiu-se a lidar com os loteamentos que se 
pretendiam regulares, nada estabelecendo para as posses, como, por exemplo, um instrumento jurídico de sua legitimação. ${ }^{22}$

É neste contexto legislativo, portanto, que o governo militar promulga a Lei $n^{\circ} 6.766$ de dezembro de 1979, na tentativa de atualizar e melhorar a regulamentação do loteamento e da apropriação do solo urbano, revogando o Decreto-lei no58 de 1937, mas mantendo muitos pontos em comum com ele. Na década de 1970, já se fazia necessária uma política propriamente urbana capaz de regular a situação fundiária que se tornara caótica devido às alternativas ilegais e irregulares de moradia que se generalizaram na ausência de uma política pública suficientemente eficaz para absorver o inchaço populacional do meio urbano que havia, naquela década, finalmente invertido a balança demográfica $^{23}$. Diante deste quadro, o parcelamento urbano - como etapa essencial do processo de urbanização, definindo seu traçado e indicando as vias de circulação, quadras, lotes e áreas públicas e/ou verdes - tem por finalidade principal o ordenamento do espaço da cidade, que, junto com o zoneamento e as regras urbanísticas tornam-se capazes de efetivar direitos fundamentais e sociais dentre os quais se destaca a moradia.

Assim, o que importa para este trabalho na Lei $n^{\circ} 6.766 / 1979$ é o procedimento de regularização que esta institui para os loteamentos e assentamentos já consolidados e/ou bastante populosos. Sendo o Município

\footnotetext{
${ }^{22}$ Neste momento também foi promulgado o Código de Obras de 1937, na então capital do país, Rio de Janeiro. Nesta década, a capital já via se consolidarem as favelas em seus morros centrais e litorâneos. À título meramente ilustrativo e por isso de breve menção, o Código de Obras de 1937 (Decreto n ${ }^{\circ}$ 6.000) reconheceu a favela no âmbito urbano, definindo-a e estabelecendo sua ilegalidade, além de proibir obras nas já existentes, condenando-as, assim, à precariedade infraestrutural.

Artigo 349: A formação de favelas, isto é, de conglomerados de dois ou mais casebres regularmente dispostos ou em desordem, construídos com materiais improvisados e em desacordo com as disposições deste Decreto, não será absolutamente permitida.

$\S 1^{\circ}$ : Nas favelas existentes é absolutamente proibido levantar ou construir novos casebres, executar qualquer obra nos que existem ou fazer qualquer construção.

$\S 2^{\circ}$ : A Prefeitura providenciará (...) por todos os meios ao seu alcance para impedir a formação de novas favelas ou para a ampliação e a execução de quaisquer obras nas existentes, mandando proceder sumariamente à demolição dos novos casebres, daqueles em que for realizada qualquer obra e de qualquer construção que seja feita nas favelas. (grifos meus, Presidência da República, 2012).

${ }^{23}$ Segundo o IBGE (2012), é na década de 1970 que o Brasil passa a ter uma população majoritariamente urbana: o Censo de '70 registrou 52.904 .744 pessoas em áreas urbanas contra 41.603.839 brasileiros no campo.
} 
responsável pela aprovação dos loteamentos e fiscalização dos mesmos (artigos 10 e 12 da lei), é ele que deverá deve tomar as medidas pertinentes à regularização do loteamento ilegal ou irregular. $\mathrm{O}$ artigo 40 da Lei $\mathrm{n}^{\circ}$ 6.766/1979, ao estabelecer que o Município ou Distrito Federal "poderá regularizar loteamento ou desmembramento não autorizado ou executado sem observância das determinações do ato administrativo de licença", estabeleceu, na verdade, um poder-dever vinculado, ou seja, positivou a regularização como obrigação do Município. Nesse sentido também se firmou a jurisprudência do Superior Tribunal de Justiça ${ }^{24}$.

A postura desta lei diante de irregularidades ou da ilegalidade dos loteamentos urbanos é favorável ao seu aproveitamento e adequação por meio da regularização. Constatada alguma irregularidade, o Município deverá notificar o loteador para saná-la, podendo firmar acordos, preferencialmente mediante termo de ajustamento de conduta (TAC), e estabelecer prazos para a regularização. Dependendo da gravidade da irregularidade, o Município deverá decretar a irregularidade do loteamento (Benedetto; Blanco, 2008, p. 338) e notificar o loteador para que se abstenha de efetuar novas vendas, para que não receba as prestações depositadas e para que forneça a relação de todos os adquirentes dos lotes e seus respectivos endereços (artigos 37 e 38 , §5 ). Com esta relação, a Prefeitura ainda deverá comunicar a irregularidade aos adquirentes para que suspendam o pagamento das prestações e passem a depositá-las perante o Registro de Imóveis, em conta bancária vinculada ao loteamento (artigo $38, \S 1^{\circ}$ ). Deverá ainda providenciar a averbação da decretação de irregularidade na matrícula do loteamento e dos respectivos lotes para que se dê publicidade formal (Benedetto; Blanco, 2008, p. 340).

Já diante da ilegalidade do loteamento, o Município deverá tomar atitude similar, reunindo documentação a ser enviada ao Ministério Público para que promova a responsabilização civil e criminal dos empreendedores. A partir de então, duas medidas poderão ser tomadas: o desfazimento do

\footnotetext{
${ }^{24}$ Vide recursos especiais $\mathrm{n}^{\circ} 1.113 .789 / \mathrm{SP}, 448.216 / \mathrm{SP}, 432.531 / \mathrm{SO}, 333.056 / \mathrm{SP}, 259.982 / \mathrm{SP}$, 252.512/SP, 191.507/SP, 131.697/SP e 124.714/SP.
} 
loteamento ou, preferencialmente, a adoção de medidas voltadas a sua regularização. A decisão de regularizar ou não compete exclusivamente ao Poder Público municipal e vai depender, acima de tudo, se a situação é reversível ou não. As ocupações consolidadas em áreas que não sejam de proteção ambiental e que não coloquem em riscos a integridade dos moradores devem ser regularizadas (Brasil, 2007, p. 124).

Ao contrário, quando se tratar de ocupação incipiente, com construções em sua fase inicial ou em área de proteção ambiental ou de risco, a prefeitura deverá embargar as obras e adotar medidas administrativas visando impedir a implantação do parcelamento, mantendo fiscalização constante e vedando o acesso ao sistema viário implantado.

Neste sentido, vale destacar ainda que no artigo 42 da referida lei o legislador estabelece a importância dos registros também na possibilidade de desapropriação: não serão considerados como loteados ou loteáveis, para fins de indenização, os terrenos ainda não vendidos ou compromissados, objeto de loteamento ou desmembramento não registrado. Apesar da previsão, a lei não estabelece o que deverá ocorrer com os moradores e ocupantes destes loteamentos não registrados, no caso de serem desapropriados.

No parcelamento do solo urbano, portanto, a lei federal se mostrou tecnicista, preocupando-se mais com o detalhamento de trâmites e procedimentos a serem cumpridos pelos loteadores e autoridades municipais do que com a garantia da distribuição dos imóveis urbanos ou com a proteção da moradia e habitação. A lei afasta a necessidade de título de propriedade ou registro de promessa de compra e venda equivalente para a regularização apenas na hipótese de parcelamento popular de imóvel declarado de utilidade pública quando houver processo de desapropriação judicial em curso e a imissão provisória da posse (artigo $18, \S \S 4^{\circ}$ e $5^{\circ}$ ). Desta forma, não é uma lei que reconhece ou valoriza a posse como forma legítima de acesso ao solo urbano, tendo apenas criado procedimentos rígidos a serem aplicados em uma realidade complexa. Dessa forma, sem dispor de instrumentos para regularizar as grandes metrópoles e sem legitimar a posse como forma de apropriação do solo para fins de moradia, as novas leis urbanas reproduzem as distorções das 
leis agrárias. O seu efeito, porém, não é o mesmo: enquanto a lei rural contribuiu para a expulsão dos trabalhadores do campo, a lei urbana não é capaz de intervir na informalidade generalizada da moradia popular, permitindo que esta se alastre ainda mais.

\subsection{Remédios legais para problemas urbanos: o novo aparato jurídico para lidar com as 'selvas de pedra'}

Por fim, o último e atual período democrático brasileiro vingou a partir da promulgação da Constituição de 1988, que tratou pela primeira vez da questão urbana diretamente, trazendo sofisticação jurídica em seus princípios urbanísticos e na diferenciação entre a função social e a usucapião especial de caráteres rural e urbana.

Após a promulgação da referida Constituição (1988), o Brasil encontrou-se finalmente aparelhado de diretrizes propriamente urbanas, permeadas de princípios e direitos fundamentais generosamente garantidos nos primeiros artigos do diploma. A conjuntura democrática que emergia após o fim do regime militar, juntamente com a necessidade de se reconstruir a economia depois do malgrado "milagre", permitiram que a nova Carta Constitucional fosse escrita com ampla participação social e excelência técnica para assegurar uma nova ordem inspirada na cidadania. Apesar dos entraves que ainda hoje impedem que se cumpra o que a Constituição possibilita, suas disposições inovadoras pautaram a produção legislativa relativa à terra e moradia do início do século XXI. No mesmo ano, duas regulamentações da política urbana prevista na Constituição foram publicadas: o Estatuto da Cidade, Lei $n^{\circ}$ 10.257, que será discutido a seguir, e a Medida Provisória $n^{\circ}$ 2.220, sobre a concessão de uso especial de terras públicas, não passíveis de usucapião, mas frequentemente ocupadas para fins de subsistência e moradia.

A nova Carta constitucional institui um patamar sólido sobre o qual se construiria a legislação e política urbana brasileira. Assim, organiza o Estado para fins urbanos - no seguinte sentido: compete à União estabelecer as 
diretrizes do desenvolvimento urbano, inclusive habitação, saneamento básico e transportes urbanos (artigo 21, XX); compete à União e aos Estados legislar concorrentemente sobre direito urbanístico (artigo 24, I); e compete aos Municípios, promover, no que couber, adequado ordenamento territorial, mediante planejamento e controle do uso, do parcelamento e da ocupação do solo urbano (artigo 30, VIII).

A execução da política urbana, com base nas diretrizes da União e legislações federais e estaduais, caberia ao Poder Executivo municipal, tendo por objetivo ordenar o pleno desenvolvimento das funções sociais da cidade e garantir o bem-estar de seus habitantes (artigo 182). Esta política urbana seria definida anteriormente, por instrumento próprio aprovado pela Câmara Municipal: o plano diretor, que é obrigatório para cidades com mais de vinte mil habitantes (artigo 182, $\S 1^{\circ}$ ). Em seguida, a Constituição define a função social da propriedade urbana especificamente, que será atendida quando cumprir com as exigências expressas no plano diretor (artigo 182, $\S 2^{\circ}$ ). Aqui, apesar da CF 1988 ter consagrado o direito à moradia com direito social (artigo $6^{\circ}$, a partir da Emenda n²6 de 2001), o legislador brasileiro perdeu a oportunidade de atrelar este à função social da propriedade, que poderia ter ganhado contornos mais definidos, necessariamente ligados aos direitos sociais e fundamentais em geral. De acordo com Tepedino (1998, 2005 e 2006), no entanto, a chave interpretativa constitucional, feita de forma sistemática nos $\operatorname{artigos} 1^{\circ}, 3^{\circ}, 5^{\circ}, 6^{\circ}, 182$ e seguintes, aponta para a tutela apenas do estatuto proprietário que atender a sua função social, sendo esta entendida no meio urbano, pela mesma lógica, como sendo a moradia e a adequada circulação e bem-estar dos cidadãos.

A Constituição de 1988 ainda prevê instrumentos incisivos sobre a propriedade urbana não aproveitada à disposição do Poder Público municipal, a serem regulados por lei específica: o parcelamento ou edificação compulsórios, IPTU progressivo no tempo e desapropriação mediante pagamento de títulos da 
dívida pública, em vez de dinheiro (artigo 182, §4º). Quanto à usucapião especial urbana, a nova Constituição definiu, em seu artigo 183, que

Aquele que possuir como sua área urbana de até duzentos e cinquenta metros quadrados, por cinco anos, ininterruptamente e sem oposição, utilizando-a para sua moradia ou de sua família, adquirir-lhe-á o domínio, desde que não seja proprietário de outro imóvel urbano ou rural [...] $\S 3^{\circ}-$ Os imóveis públicos não serão adquiridos por usucapião (Presidência da República, 2012).

O prazo de cinco anos, o mais curto até então previsto e estendido também ao tipo rural, que, segundo Marco Aurélio Bezerra de Melo (2008, p.95), que está atrelado ao cumprimento da função social da posse, aponta para a urgência da reestruturação que a usucapião especial poderia promover. Para Betânia Alfonsin (2002, p. 152), a inclusão do artigo 183 na CF implica o reconhecimento da falência da política habitacional no país. Milhares de famílias "autoconstruíram suas moradias em terrenos vazios que foram 'ocupados' para que essa população pobre pudesse exercer o mais elementar dos direitos humanos: o direito de morar". No entanto, o instrumento não se mostrou veloz nem abrangente, na medida em que a via judicial se provou morosa e, às vezes, inacessível.

Ainda para Melo (2008), pelo modo que a usucapião especial urbana foi inserida na Constituição, com a participação massiva das entidades comprometidas com a defesa da moradia, havia um maior otimismo em torno da eficácia deste instituto, principalmente na regularização fundiária de favelas. Para o autor, dois fatores inibiram o sucesso do instrumento: a jurisprudência consolidada do STF referente à aplicabilidade da usucapião especial urbana apenas às posses que tivessem seu início em data anterior a 5 de outubro de 1988; e a impossibilidade de se valer coletivamente da usucapião especial urbana (Melo, 2008, p. 95-96).

A regulamentação do instituto e de alguns outros instrumentos urbanos constitucionalmente previstos, só sobreveio com o Estatuto da Cidade em 2001, que adicionou à nova espécie de usucapião especial a possibilidade de 
ser pleiteada e concedida coletivamente, com frações ideais da posse e da propriedade.

O Estatuto da Cidade, a par de regulamentar o Capítulo da Política Urbana da Constituição de 1988 (artigos 182 e 183), revigora, sem dúvida, a noção de função social da propriedade urbana, conferindolhe força nova e redobrada aplicabilidade, tendo em vista que suas normas consolidam o moderno paradigma de propriedade antes mencionado (Mattos, 2006, p. 50).

Grande conquista legislativa, o Estatuto da Cidade detalhou uma série de instrumentos de ordenamento, zoneamento e aproveitamento do solo urbano, abrindo portas para formas diversas de garantir a moradia. Dentre seus objetivos elencados no artigo $2^{\circ}$, aponta a seguinte:

Art. $2^{\circ}$ A política urbana tem por objetivo ordenar o pleno desenvolvimento das funções sociais da cidade e da propriedade urbana, mediante as seguintes diretrizes gerais:

[...]

IV - regularização fundiária e urbanização de áreas ocupadas por população de baixa renda mediante o estabelecimento de normas especiais de urbanização, uso e ocupação do solo e edificação, consideradas a situação socioeconômica da população e as normas ambientais; [...] (grifos meus, Presidência da República, 2012).

O Estatuto, reconhecendo a ocupação, avança em relação à legislação anterior que tratava apenas de áreas em viés de parcelamento e ainda desconsiderava aqueles cujos termos não estivessem registrados. Ainda, inova ao mencionar na letra da lei a "edificação", consolidando definitivamente a possibilidade de se usucapir casas, prédios ou outras construções "invadidos", incluindo unidades edilícias. A lei, portanto, prevê uma série de instrumentos para garantir o cumprimento das funções sociais da propriedade e da cidade, como o parcelamento, edificação ou utilização compulsórios (seção II), o IPTU progressivo no tempo (seção III) e a desapropriação com pagamento em títulos (seção IV), antes de tratar da usucapião especial urbana (seção V).

Infelizmente, o texto legal abriu brechas para que alguns destes instrumentos permanecessem sem aplicação, ao prever necessidade de lei específica municipal para regular o parcelamento, edificação ou utilização compulsórios (artigo $5^{\circ}$ ) e ligando a este os outros instrumentos, como ilustra o artigo $8^{\circ}$ da lei: 
Art. $8^{\circ}$ Decorridos cinco anos de cobrança do IPTU progressivo sem que o proprietário tenha cumprido a obrigação de parcelamento, edificação ou utilização, o Município poderá proceder à desapropriação do imóvel, com pagamento em títulos da dívida pública (grifos meus, Presidência da República, 2012).

Sendo assim, a usucapião especial urbana permanece como o principal instrumento de acesso à propriedade, consumando-se no tempo pela posse mansa e pacífica, sem necessidade de legislação superveniente. Além disso, buscou-se com esta usucapião especial um maior comprometimento dos proprietários quanto à utilização da propriedade urbana, de forma que essa propriedade possa cumprir sua função social, sob pena de perda do direito real:

Por essa modalidade, visava o constituinte proporcionar um maior comprometimento dos proprietários de áreas urbanas com o seu patrimônio, cobrando desse proprietário que desse ao seu patrimônio a efetiva utilização, atendendo assim a sua função social, sob pena de, não o fazendo, perder a sua titularidade em favor daquele que efetivamente o utilizasse como sua moradia e de sua família, por no mínimo cinco anos, não sendo proprietário de outro imóvel urbano ou rural, mesmo não possuindo justo título e independentemente de boa-fé. Note-se, portanto, que essa modalidade, como na modalidade constitucional rural, o público que o constituinte visou alcançar era um público muito específico: o público de baixa renda, que utilizasse o imóvel alheio desocupado, fazendo-o para suprir as suas necessidades básicas, moradia e sustento (Souza, 2009, p. 95).

O Estatuto da Cidade definiu a usucapião especial urbana em seus artigos $9^{\circ}$ e 10, dando-lhe duas modalidades possíveis: individual e coletiva, respectivamente. Pela redação dos artigos, fica clara a opção do legislador ainda pela via judicial para a declaração do direito adquirido, servindo a sentença como título registrável de propriedade. No entanto, o Estatuto perde oportunidade aproveitada no Código Civil, já comentado, quando este esclarece de uma vez por todas que a usucapião - a aquisição da propriedade - se configura independentemente da sentença judicial, sendo esta apenas declaratória. Entendimento sustentado por maior parte da doutrina e jurisprudência, esta ainda encontra-se acolhido em lei anterior ao Código e ao Estatuto. Lê o artigo 167, item 28 da Lei de Registros de Imóveis (nº 6.015 de 1973), que além da matrícula, será feito o registro das "sentenças declaratórias de usucapião". 
O $\operatorname{artigo~} 9^{\circ}$, que versa sobre usucapião especial urbana individual, não previu nenhuma mudança em relação ao previsto em 1988. A novidade está no artigo 10, onde o Estatuto da Cidade reconheceu a complexidade dos assentamentos irregulares e ilegais das metrópoles brasileiras, como as favelas e mocambos, buscando reconhecer a propriedade coletiva pela usucapião. De acordo com esse dispositivo, as áreas urbanas com mais de $250 \mathrm{~m}^{2}$ ocupadas por população de baixa renda para sua moradia, por cinco anos, ininterruptamente e sem oposição, onde não for possível identificar os terrenos ocupados por cada possuidor, são suscetíveis de serem usucapidas coletivamente, desde que os possuidores não sejam proprietários de outro imóvel urbano ou rural.

Neste sentido, cabem os ensinamentos de Cristiano Chaves de Farias e Nelson Rosenvald (FARIAS; ROSENVALD, 2006, p. 298, grifos meus):

A usucapião coletiva de imóveis particulares é forte instrumento de função social da propriedade, uma vez que permite uma alternativa de aquisição de propriedade em prol de possuidores que não tenham acesso a ações individuais de usucapião porque o imóvel está encravado em loteamento irregular ou porque a área possuída é inferior ao módulo urbano mínimo. Com a opção da usucapião coletiva, o legislador retirou a injustiça da prevalência da forma sobre o fundo, permitindo-se não só a aquisição da propriedade pela comunidade de possuidores, como a urbanização da área e ampliação de serviços públicos sobre os imóveis.

[...] a usucapião coletiva detém a notável capacidade de favorecer os interesses individuais homogêneos da coletividade que anseia pelo direito de propriedade, com a vantagem de que a decisão coletiva impede que sejam mantidos os cortes efetuados por cada possuidora cada família será atribuída uma fração ideal do imóvelpossibilitando a urbanização racional da área como um todo.

Na usucapião coletiva, portanto, permite-se a aquisição do título sem quaisquer restrições tradicionais atreladas à noção clássica de propriedade privada, intrinsicamente ligada ao indivíduo. Assim, segundo o Estatuto da Cidade, em razão da não individualização da área ocupada, o juiz deverá atribuir fração ideal do terreno a cada possuidor, independentemente da dimensão da parcela que cada um ocupe, salvo hipótese de haver acordo escrito entre os condôminos, estabelecendo frações ideais diferenciadas (artigo 10, $\left.\S 3^{\circ}\right)$. Não obstante o entendimento ainda tradicionalista dos tribunais, 
insistindo na individualização dos lotes e cobrando nas ações demasiado formalismo, uma Juíza de Direito da $3^{\text {a }}$ Vara Cível do Tribunal de Justiça do Rio de Janeiro concedeu a primeira usucapião especial urbana coletiva do Estado, no processo de $n^{\circ}$ 2005.001.093.676-0, em 12 de setembro de 2011. Destaca-se da fundamentação de sua decisão:

Destarte, se há propriedade condominial, coletiva, pois, não há razão jurídica para se inadmitir a aquisição coletiva de propriedade, inclusive pela via da usucapião, inexistindo qualquer vedação a isso no inciso XXII do art. $5^{\circ}$ da Constituição. [...] Doutra parte, a superação da deterioração urbana e das patologias favelares, com lastro na principiologia constitucional (particularmente, mas não só: função social da propriedade, art. 170, II e III; defesa do meio ambiente, idem, inciso VI; redução das desigualdades sociais, idem, inciso VI; garantia do bem-estar dos habitantes da cidade, art. 182, caput; harmonia social, preâmbulo; dignidade da pessoa humana, art. $1^{\circ}$, III; justiça e solidariedade sociais, art. $3^{\circ}, \mathrm{I}$; erradicação da pobreza e marginalização, art. $3^{\circ}$, III), confere inequívoco lastro jurídico à inovação do usucapião coletivo, na busca de soluções para a questão da submoradia (grifos meus).

Visando uma prestação jurisdicional mais célere, o Estatuto da Cidade ainda estabeleceu o rito sumário para as ações de usucapião especial urbana, (artigo 14). Foram consideradas partes legítimas para propor as ações tanto o possuidor, isoladamente ou em litisconsórcio originário ou superveniente, os possuidores, em estado de composse e a associação de moradores da comunidade, regularmente constituída, com personalidade jurídica, desde que explicitamente autorizada pelos representados, como substituto processual (grifos meus, artigo 12 e incisos). Isto indica que mesmo processualmente, a lei objetiva viabilizar o reconhecimento da usucapião de formas mais coletivas possíveis, mesmo em casos onde o título a ser registrado for individual. Além disso, para melhor prestação jurisdicional, permitiu-se que a usucapião especial de imóvel urbano seja invocada como matéria de defesa, valendo a sentença favorável do réu como título diante do Registro de Imóveis (artigo 13).

Logo em seguida, no mesmo contexto democrático e moderno, também promulgou-se outro diploma central - o novo Código Civil de 2002 - que estendeu a função social já atrelada à propriedade e à cidade, aos contratos. Além disso, sistematizou as diferentes espécies de usucapião: 
Art. 1.238. Aquele que, por quinze anos, sem interrupção, nem oposição, possuir como seu um imóvel, adquire-lhe a propriedade, independentemente de título e boa-fé; podendo requerer ao juiz que assim o declare por sentença, a qual servirá de título para o registro no Cartório de Registro de Imóveis. [usucapião extraordinário]

Parágrafo único. O prazo estabelecido neste artigo reduzir-se-á a dez anos se o possuidor houver estabelecido no imóvel a sua moradia habitual, ou nele realizado obras ou serviços de caráter produtivo.

Art. 1.239. Aquele que, não sendo proprietário de imóvel rural ou urbano, possua como sua, por cinco anos ininterruptos, sem oposição, área de terra em zona rural não superior a cinquenta hectares, tornando-a produtiva por seu trabalho ou de sua família, tendo nela sua moradia, adquirir-lhe-á a propriedade. [usucapião especial rural]

Art. 1.240. Aquele que possuir, como sua, área urbana de até duzentos e cinquenta metros quadrados, por cinco anos ininterruptamente e sem oposição, utilizando-a para sua moradia ou de sua família, adquirir-lhe-á o domínio, desde que não seja proprietário de outro imóvel urbano ou rural. [usucapião especial urbana]

$[\ldots]$

Art. 1.242. Adquire também a propriedade do imóvel aquele que, contínua e incontestadamente, com justo título e boa-fé, o possuir por dez anos. [usucapião ordinário]

Parágrafo único. Será de cinco anos o prazo previsto neste artigo se o imóvel houver sido adquirido, onerosamente, com base no registro constante do respectivo cartório, cancelada posteriormente, desde que os possuidores nele tiverem estabelecido a sua moradia, ou realizado investimentos de interesse social e econômico.

O novo Código sutilmente indica a força do instituto ao prever a sentença declaratória como forma de mera declaração - e não de atribuição ou requisito para a aquisição - da propriedade: poderá o possuidor requerer ao juiz seja declarada adquirida, mediante usucapião, a propriedade imóvel (artigo 1.241), declaração esta que constituirá título hábil para o registro no Cartório de Registro de Imóveis (parágrafo único do art. 1.241). Ainda, nas categorias usucapiendas ordinária e extraordinária, o novo Código também consagra a força da função social do solo ligada à moradia, diminuindo os prazos para a aquisição de habitantes do imóvel nesta modalidade. Assim, a funcionalização de institutos jurídicos importantes como a posse, a propriedade e até mesmo os contratos, se consolidou definitivamente no século XXI, apontando para a humanização de conceitos abstratos e tradicionalmente 
sustentados por si mesmos, sem que fossem atrelados às consequências que geravam na sociedade. Assim, afasta-se da interpretação de cunho apenas sociológico da 'função social', que por vezes se revestia de ideologias contraditórias, aproximando-se de um conceito técnico-jurídico consistente.

Mesmo assim, entraves da via judicial retiram a efetividade do instituto, sendo exigidas pelo juízo citações pessoais do proprietário e dos confinantes e por edital de eventuais interessados, juntadas de plantas, certidões infinitas de dos cartórios de Registro de Imóveis, perícias, oitiva do Ministério Público e das Fazendas Públicas das três instâncias, entre outras diligências, arrastando o proprietário, sujeito do direito - uma vez que a sentença é apenas declaratória por uma verdadeira via crucis burocrática e morosa, o que acaba estimulando a manutenção da informalidade. Sem oferecer alternativa à via judicial para o reconhecimento da propriedade pela usucapião - como havia feito a regulamentação da usucapião especial rural no artigo $4^{\circ}$, $\$ 2^{\circ}$ da Lei $n^{\circ}$ 6.969/1981 - o Estatuto ainda requer complementação legislativa, específica sobre as muitas possibilidades que abre para este instituto.

Releve-se, ademais, a própria morosidade do procedimento judicial como contributo para o desencanto, esmorecimento e consequente desprezo por parte dos interessados em buscarem a regularidade de suas titularidades em juízo, valendo mais à pena manter-se na cidade informal com as suas doses perniciosas de exclusão social do que enfrentar os dissabores de uma ação judicial deveras burocrática (Melo, 2008, p. 139). 


\section{CAPÍTULO 3}

\section{A Lei no 11.977 de 2009 e o processo administrativo para a usucapião em âmbito urbano}

Diante dos avanços promovidos pela Constituição de 1988, Código Civil de 2002 e Estatuto da Cidade de 2001, a conjuntura do século XXI, favorável às regularizações fundiárias em áreas urbanas, produziu instrumentos para garantir sua efetivação. Não obstante, os meios disponíveis para a concretização da função social da propriedade ainda padecem de insuficiência legislativa, como o parcelamento, edificação ou utilização compulsórios, ou necessitam de maior clareza em seus trâmites legais. Do ponto de vista do professor Edésio Fernandes (2007, p. 51), [...]

A ilegalidade urbana tem sido provocada não só pela combinação
entre a dinâmica dos mercados de terras e o sistema político, mas
também pela ordem jurídica elitista e excludente ainda em vigor nos
países em desenvolvimento como o Brasil. Legalizar o ilegal
requer a introdução de estratégias jurídico-políticas inovadoras que
conciliem o reconhecimento do direito de moradia com a
permanência das comunidades nas áreas onde vivem (grifos meus).

Tais estratégias jurídico-políticas, assim nomeadas por Fernandes, sugerem imediatamente alternativas extrajudiciais. No entanto, também reportam às conclusões de Holston (1993) sobre a prática da usurpação e posterior legalização no sistema fundiário brasileira. Inicialmente garantindo a formação e manutenção de latifúndios, a legalização perversa de grilagens, apropriações e expulsões promovidas por senhores e fazendeiros, transportada para o meio urbano, passa a ser a legalização necessária de posses, ocupações e "invasões" para fins de moradia de trabalhadores pobres e expropriados. Estas legalizações, porém, são intentadas frequentemente pela via judicial, que é historicamente favorável aos detentores de títulos - mesmo que estes tenham sido outorgados pelos próprios titulares, como eram as cartas de doações que fundaram o sistema fundiário brasileiro. Neste sentido, os tribunais ainda hoje mantém postura tradicional e formalista diante da propriedade, não obstante sua função social e a valorização da posse para a usucapião. 
No Brasil, ainda, o recente fenômeno de judicialização dos direitos desencadeado pela Constituição de 1988 aponta para a ineficiência das ações do Poder Executivo. Como consequência, os tribunais nacionais foram inundados por processos visando a concretização de um ou mais direitos do extensivo rol garantido na $\mathrm{CF}$, desafiando sua capacidade e celeridade e tornando necessário a criação de novas varas, a formação de novos juízes, etc. Paralelamente, passou-se a repensar a participação obrigatória do Judiciário em diversos processos onde concedia mera homologação ou garantia reconhecimento de direitos feitos com acompanhamento dos cartórios de Registro de Imóveis.

Neste sentido, passou-se a falar do fenômeno de desjudicialização de algumas relações jurídicas entre particulares, que será tema da primeira parte deste capítulo. No entanto, a desjudicialização, aumentando o papel e a responsabilidade dos Registros de Imóveis na comprovação e proteção de direitos ou na resolução e regramento de relações pessoais, torna necessária uma maior atenção à concessão e fiscalização desta atividade registral. É por isso que o fenômeno será discutido à luz da questão dos registros públicos e sua evolução no Brasil.

Exemplificando as diversas leis que se valeram da desjudicialização para dar celeridade a trâmites e pedidos antes processuais, o capítulo segue à análise da Lei no 11.977 de julho de 2009, que, tendo convertido a Medida Provisória n 459 do mesmo ano, passa a regular a execução do programa habitacional federal "Minha Casa, Minha Vida" e institui importantes instrumentos de regularização fundiária das cidades. Explica a Mensagem Interministerial $\mathrm{n}^{\mathbf{o}}$ 33, servido de exposição de motivos para a MP nº459:

Apesar dos esforços dos governos federal, estaduais e municipais, os resultados alcançados ainda estão aquém do necessário, dada a ausência de um marco regulatório específico para a questão da regularização fundiária urbana, o que tem causado enormes entraves e dificuldades para que a regularização fundiária seja efetivada até $\mathrm{o}$ fim. [...] A lacuna legal existente dá margem a interpretações dúbias, conflitantes e até mesmo arbitrárias da legislação existente que trata, quando muito, de modo indireto e superficial da questão, trazendo grandes prejuízos àqueles que seriam os beneficiários 
diretos das ações de regularização. Assim, a presente proposta de Medida Provisória procura estabelecer o arcabouço legal necessário para tornar mais efetivo e célere o rito da regularização fundiária urbana (grifos meus, Presidência da República, 2012, Pontos 34 e 35 da E.M. Interministerial $n^{\circ} 33 / 2009$ ).

Trazendo uma concepção branda de regularização fundiária, que inclui não apenas a titulação dos proprietários, mas a adequação do assentamento aos padrões urbanísticos e de provisão de serviços vigentes, a nova lei também estabelece um procedimento administrativo detalhado para realizá-la. De definições conceituais às novas regras da atividade cartorial, a lei cria o registro eletrônico de imóveis e reduz as custas registrais.

As medidas sugeridas estabelecem critérios gerais para a regularização de assentamentos e garantia da segurança da posse urbana, buscando compatibilizar direto à moradia e direito ambiental, reconhecendo o papel preponderante do Município em regulamentar por lei o procedimento de regularização fundiária em seu território, como parte integrante da política urbana de inclusão social, definindo regras nacionais e específicas para o registro dos parcelamentos advindos dos projetos de regularização fundiária e instituindo os instrumentos de demarcação urbanística e legitimação da posse que acelerem o reconhecimento de direitos constituídos na forma do artigo 183 da Constituição Federal (Presidência da República, 2012, Ponto 36 da E.M. Interministerial n³3/2009).

Procurando regularizar todos os tipos de assentamentos irregulares, a lei os define como ocupações inseridas em parcelamentos informais ou irregulares, localizadas em áreas urbanas públicas ou privadas, utilizadas predominantemente para fins de moradia (artigo 47, VI). Assim, ainda prevê dois gêneros de regularização: de interesse social e de interesse específico, sendo apenas a primeira o objeto de análise deste capítulo. Isto porque é a regularização fundiária de interesse social que, em suas modalidades, cria o procedimento extrajudicial de reconhecimento da usucapião especial urbana.

Assim, a segunda parte deste capítulo dedica-se à compreensão deste novo procedimento de reconhecimento da usucapião pela regularização fundiária de interesse social, por meio da ressuscitação do instrumento da legitimação da posse. Outras inovações trazidas pela Lei no 11.977/2009, referentes ao processo de regularização que acompanha a usucapião administrativamente reconhecida, serão abordadas, como a concessão de 
legitimidade ativa para os próprios beneficiários da regularização, individual ou coletivamente, a promoverem em parceria com o Poder Público municipal.

Mesmo recente, as regulamentações urbanísticas previstas na Lei $\mathrm{n}^{\circ}$ 11.977 de 2009 já sofreram alterações posteriores pela Lei $n^{\circ} 12.424$ de 2011, que adapta diversos artigos e parágrafos do capítulo da lei que é do interesse deste trabalho, referente à regularização fundiária de assentamentos urbanos. Assim, também serão consideradas estas alterações e os desdobramentos que geraram especialmente no que diz respeito à eficiência dos procedimentos previstos.

Por fim, o presente capítulo irá analisar os potenciais dos procedimentos criados pelas novas legislações, na medida em que procuram dar celeridade e efetividade à regularização, substituindo a via judicial por uma burocrática, mas criam novos entraves próprios destes trâmites administrativos. Assim, pretende-se abordar até que medida a Administração Pública municipal e os Registros de Imóveis serão capazes de oferecer melhor soluções que o Judiciário, especialmente no que diz respeito ao reconhecimento do direito de propriedade adquirido por meio da usucapião especial urbana.

\subsection{0 fenômeno da desjudicialização no ordenamento jurídico brasileiro e o impacto sobre os registros públicos}

O auge do fenômeno de desjudicialização no ordenamento brasileiro foi alcançado com a Lei de Arbitragem ( $\mathrm{n}^{\circ}$ 9.307) de setembro de 1996, que permitiu que as partes escolhessem árbitros e procedimentos de resolução de seus conflitos fora do Judiciário. Tratando-se de relações e direitos patrimoniais disponíveis, a arbitragem, escolhida por cláusula compromissória e compromisso arbitral, acarreta efeitos de trânsito em julgado. Sabatinada pelo Código de Processo Civil, o artigo 267, inciso VII prevê a extinção do processo, sem resolução do mérito, das ações entre partes cujo contrato disputado preveja a arbitragem. Assim, iniciou-se a relativização do preceito de inafastabilidade da jurisdição, que, na maioria dos casos em que houve a 
desjudicialização, ainda pode ser acionada em caso de deflagração de conflito de interesses e direitos.

Além desta, a Lei $\mathrm{n}^{\circ} 11.101$ de fevereiro de 2005 criou um mecanismo flexível para a recuperação e falência de empresários, contrastando com a rigidez da Lei $n^{\circ} 7.661 / 1945$ e instituindo a recuperação extrajudicial. Nesta linha, a Lei $\mathrm{n}^{\circ} 11.441$ de janeiro de 2007 também permite que inventários, partilhas, separações e divórcios consensuais sejam realizados por via administrativa, juntos aos respectivos cartórios e órgãos competentes sem a necessidade de intervir o juízo. Junto aos Registros de Imóveis também foram criadas inovações, como retificações em registro imobiliários feitas diretamente pelo oficial habilitado, provocando o Judiciário apenas em casos de conflito entre as partes (Lei $\mathrm{n}^{\circ} 10.931$ de 2004), e registros de nascimento após o decurso do prazo legal após o qual se requeria, antes, a intervenção judicial para se realizar (Lei ${ }^{\circ} 11.790$ de 2008).

Doravante, para tais providências é bastante a atuação na esfera administrativa, através de escritura pública, quando as partes interessadas forem maiores e capazes e desde que estejam acordes (isto é, não exista conflito de interesses) quanto aos termos do ajuste dissolutório do casamento ou da partilha dos bens transmitidos por morte. Sem dúvida, essa boa nova processual (que, a toda evidência, está inserta nesse grande espectro de reformas processuais antes aludido) efetiva a busca por um processo civil mais célere e concreto e, por certo, constitui notável avanço da legislação brasileira, importando, reflexamente, em maior racionalização das atividades do Ministério Público no processo civil além de desafogamento das assoberbadas prateleiras do Judiciário, especialmente quando considerada a grande quantidade de ações consensuais proposta em nosso foro (Farias, 2007, p. 7-8).

Sendo assim, a desjudicialização não implicaria na recusa ou na proibição da prestação jurisdicional, protegida pelos princípios de devido processo legal e inafastabilidade da jurisdição, definidos no artigo $5^{\circ}$ da CF88. Segundo Marco Antônio Bezerra de Melo (2008, p. 142):

O fenômeno da desjudicialização das relações jurídicas pode ser compreendido como uma prática em que se busca um mecanismo exógeno ao Poder Judiciário, a fim de se ver alcançado um resultado efetivo do direito sem a intervenção direta da atividade jurisdicional. Assim, sempre que houver a possibilidade de se ter um resultado justo para alguma pretensão e esta puder ficar a cargo 
das partes e de outros agentes do Estado, é legítima a busca desse procedimento que além de ser mais efetivo, é também o que acarreta menores ônus para o Estado e para as partes.

Ainda, a desjudicialização é a própria busca por vias alternativas para fazer valer acordos e direitos pelo simples reconhecimento público destes, relegando ao Poder Judiciário apenas os casos diretamente relacionados à sua função precípua de resolução de litígios, de tutela de direitos ameaçados e de pacificação de conflitos em caráter definitivo. Trata-se, portanto, de uma forma de evitar o acesso desnecessário e injustificado à jurisdição, sem comprometer a garantia dos direitos de ninguém: uns terão a facilidade dos cartórios para que outros possam ter suas ações apreciadas com maior diligência jurisdicional. No entanto, não é tão simples a questão dos Registros Públicos no Brasil. Regulados pela Lei Federal $\mathrm{n}^{\circ} 6.015$ e dezembro de 1973, tais registros abrangem os registros civis de pessoas naturais e jurídicas, o registro de títulos e documentos e o registro de imóveis (artigo $1^{\circ}, \S 1^{\circ}$ ). Para este trabalho, interessa a desjudicialização da usucapião proposta pela nova legislação urbanística, e, por estarem atrelados a esta, interessam os registros públicos de imóveis.

Desde sua previsão legal no ordenamento brasileiro no Código Civil de 1916, a usucapião só poderia ser reconhecida mediante sentença declaratória, mantendo-se controle judicial sobre a aquisição da propriedade pela posse, geralmente promovida por pessoas de baixa renda na tentativa de garantir a sua subsistência e sua moradia. A desjudicialização desta aquisição - sempre reconhecida no ordenamento, mas também de sempre difícil concretização significa a última quebra com o conceito liberal e absolutista da propriedade, em prol de um entendimento mais humano e flexível deste instituto. Assim, a possibilidade de ter reconhecida a usucapião pela via administrativa, junto à autoridade competente municipal e ao Registro de Imóveis, é definitivamente uma conquista. Com isso, consolidou-se a força aquisitiva deste instrumento, que se consuma antes mesmo de ser declarado, e acabou-se com a dominação judicial das questões envolvendo propriedade de bens imóveis. 
Certos que são os avanços quanto ao sistema registral brasileiro, a retrospectiva histórica oferecida neste trabalho aponta para as origens confusas e ineficientes dos registros de imóveis. Sua primeira previsão nacional na Lei de Terras de 1850, os denominados "registros paroquiais" eram mantidos em aliança com funcionário e membros da Igreja (vigários) e continham uma série de imprecisões e confusões quanto aos limites das propriedades, seus titulares e sucessores e as posteriores transformações, parcelamentos e alienações referentes ao imóvel. Tais registros foram posteriormente regulados por duas leis antes da atual, o Decreto ${ }^{\circ} 18.542$ de 1928 e o Decreto $n^{\circ} 4.857$ de 1939 , que buscaram clarificar os procedimentos cartoriais e organizar as suas concessões para pessoas que exerceriam os cargos de notários e oficiais de registros com responsabilidade.

Atualmente, a atividade registral já é entendida como compondo um ramo próprio do direito, consistindo, segundo a professora Maria Helena Diniz (2000, p. 49),

[num] complexo de normas jurídico-positivas de princípios atinentes ao registro de imóveis que regulam a organização e o funcionamento das serventias imobiliárias: a atividade cartorária do oficial titular e de seus prepostos que agem por delegação do Poder Público, conferindo-lhes fé pública em todos os atos que autonomamente praticarem, atendendo ao interesse da coletividade e à técnica dos atos registrários (grifos meus).

Por isso, os Registros de Imóveis devem atender a princípios como o da legalidade, da publicidade, da obrigatoriedade, da tipicidade, da continuidade, da especialidade e, dentre outros, da territorialidade, uma vez que os documentos que produz são dotados de força probatória e de presunções de legitimidade e de veracidade. Dentre estes princípios, os da continuidade e da especialidade são os que mais sofrem com a herança registral da época colonial e com o fracasso da tentativa registral da Lei de Terras de 1850. Isso porque a continuidade exige que haja um encadeamento cronológico comprovável na transferência e transformação dos títulos imobiliários, e a especialidade, requer que estes estejam identificados de forma pormenorizada, com detalhes sobre as características físicas, sociais e fiscais do bem registrado. 
No caso da usucapião, uma vez declarada, o Registro de Imóveis deveria ter poucas dificuldades para registrar a propriedade, uma vez que esta é adquirida originariamente, como se nova matrícula imobiliária fosse aberta (como muitas vezes ocorre), não incidindo nenhum imposto ou encargo relativo às transferências de titularidade, mesmo havendo proprietários anteriores conhecidos. No entanto, até que a usucapião seja declarada - ou seja, enquanto encontra-se em seu trâmite judicial - o Registro de Imóveis pode causar demoras e entraves no processo. A via judicial frequentemente exige uma série de comprovações por parte dos cartórios, bem como baseia seus mandados de citação nos endereços lá constantes. No entanto, também é comum que os registros de imóveis usucapiendos - e, assim, provavelmente abandonados pelos proprietários ou de fato devolutos - não estejam atualizados, ou mesmo, inexistam. Assim, a combinação entre morosidade judicial e lacunas cartoriais representou grande obstáculo para a declaração de usucapião pelo procedimento no Judiciário.

\subsection{0 procedimento administrativo da usucapião urbana: a legitimação de posse e seus efeitos}

A referida Lei $\mathrm{n}^{\circ} 11.977$ de 2009, portanto, abriu nova alternativa para o reconhecimento da usucapião no meio urbano. O novo procedimento está inserido em uma proposta de regularização fundiária maior do que apenas a titulação da propriedade que a usucapião acarreta, abrangendo também a adequada urbanização e integração dos serviços urbanos aos assentamentos irregulares. Assim, a Lei $\mathrm{n}^{\circ} 11.977$ previa a relação entre a regularização fundiária de interesse social e a usucapião como sendo:

Art. 47 Para efeitos da regularização fundiária de assentamentos urbanos, consideram-se: [...]

VII - regularização fundiária de interesse social: regularização [...] de assentamentos irregulares ocupados, predominantemente, por população de baixa renda, nos casos:

a) em que tenham sido preenchidos os requisitos para

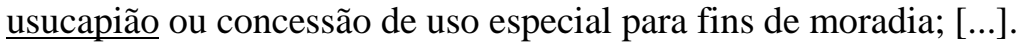


Desta forma, originalmente não se especificava a usucapião especial urbana, empregando-se genericamente o termo "usucapião", mas sem prejuízo da opção pela citada modalidade. Atualmente, porém, a alínea a aqui citada já tem outra redação, dada pela Lei no 12.424 de 2011:

Art. 47 Para efeitos da regularização fundiária de assentamentos urbanos, consideram-se: [...]

VII - regularização fundiária de interesse social: regularização [...] de assentamentos irregulares ocupados, predominantemente, por população de baixa renda, nos casos:

a) em que a área esteja ocupada, de forma mansa e pacífica, há, pelo menos, 5 (cinco) anos; [...].

A reforma do texto da nova lei por outra ainda mais recente é indicativa da urgência da questão. Ainda, o conteúdo do novo enunciado aponta para o afastamento de formalismos, substituindo referências a institutos regulados e complexos, pela mera menção de ocupação há cinco anos como suficientes para que o assentamento seja considerado para a regularização fundiária, podendo, cabe relembrar, ser proposta pelos próprios beneficiários. Em outros incisos do citado artigo estão definidos também os dois principais instrumentos de regularização criados por esta lei: a demarcação urbanística, cujo auto é relativo apenas à caracterização do imóvel e a identificação de seus ocupantes (artigo 47, III), e a legitimação de posse, ato do poder público destinado a conferir título de reconhecimento de posse de imóvel objeto de demarcação urbanística, com a identificação do ocupante e do tempo e natureza da posse (artigo 47, IV). Sobre estes, a Lei no 12.424/2011 incluiu parágrafo ao artigo 47 para esclarecer que: a demarcação urbanística e a legitimação de posse de que tratam os incisos III e IV deste artigo não implicam a alteração de domínio dos bens imóveis sobre os quais incidirem, o que somente se processará com a conversão da legitimação de posse em propriedade, nos termos do art. 60 desta lei (artigo 47, $\$ 1^{\circ}$ ).

De acordo com a atual redação da Lei n ${ }^{\circ} 11.977$ de 2011, os detentores de sentença declaratória de usucapião não terão a possibilidade de registro desta afetado pelas novas exigências e procedimentos previstos para a regularização fundiária (artigo $51, \S 1^{\circ}$ ). Aqueles que já tiverem, portanto, seu 
direito de propriedade reconhecido, poderão integrar o projeto de regularização no que se refere aos aspectos urbanísticos deste. Por sua vez, aqueles que pretendem adquirir a propriedade de acordo com o trâmite extrajudicial regulamentado neste diploma, deverão observar o procedimento previsto nos artigos 53 a 60, que será detalhado a seguir.

Cabe esclarecer que para fins de promoção da regularização fundiária de interesse social, o principal instrumento é o projeto descrito no artigo 51, que demanda a reunião de elementos como: (I) a definição das áreas ou lotes a serem regularizados e, se houver necessidade, as edificações que serão relocadas; (II) as vias de circulação existentes ou projetadas e, se possível, as outras áreas destinadas a uso público; (III) as medidas necessárias para a promoção da sustentabilidade urbanística, social e ambiental da área ocupada, incluindo as compensações urbanísticas e ambientais previstas em lei; (IV) as condições para promover a segurança da população em situações de risco, considerado o disposto no parágrafo único do art. $3^{\circ}$ da Lei ${ }^{\circ}$ 6.766, de 19 de dezembro de 1979; e, (V) as medidas previstas para adequação da infraestrutura básica. Este projeto ou plano - apesar de poder ser elaborado e proposto pelos próprios beneficiários e por organizações e associações legitimadas pela lei (artigo 50) - só poderá ser levado adiante caso seja aprovado pelo Município nos termos do artigo 53. Neste sentido ainda, a lei equipara esta aprovação municipal ao licenciamento ambiental e urbanístico do projeto, não restando dúvidas quanto ao papel protagonista da Prefeitura na sua implantação da regularização fundiária.

O papel do Poder Público é previsto, ainda, no artigo 55, que determina caber a este e aos seus concessionários e permissionários de serviços básicos a implantação do sistema viário e da infraestrutura básica nos assentamentos, incluindo aqueles cuja regularização seja promovida pelos interessados diretos. Completa no parágrafo único: a realização de obras de implantação de infraestrutura básica e de equipamentos comunitários pelo poder público, bem como sua manutenção, pode ser realizada mesmo antes de concluída a 
regularização jurídica das situações dominiais dos imóveis. Esta previsão, aparentemente simples, tem grande importância em perspectiva histórica, na qual a ausência de título de propriedade serviu de justificativa, mesmo que apenas implícita, para a manutenção das condições de precariedade dos assentamentos urbanos do país em termos de investimentos públicos em infraestrutura e serviços.

Não obstante a centralidade do projeto de regularização para a sua realização, o artigo 56 aponta para medida administrativa anterior que pode ser tomada exclusivamente pela autoridade pública para garantir a regularização fundiária de interesse social: a demarcação urbanística. Facultativo ao poder público, o auto de demarcação urbanística tem por objetivo dar início ao processo de titulação dos moradores cujo assentamento será regularizado, podendo lavrá-lo antes ou depois da apresentação do projeto do artigo 51. Assim, por ser este uma etapa burocrática da titulação, deverá ser instruído com os documentos previstos no artigo $56, \S 1^{\circ}$, tal como planta e memorial descritivo da área regularizanda, a planta de sobreposição do imóvel demarcado com a situação da área conforme o registro de imóveis e a certidão de matrícula ou transcrição da mesma área, emitida pelo referido registro, ou, diante de sua inexistência, das circunscrições imobiliárias anteriormente competentes. É imperativo que o formalismo obste a averbação deste auto de demarcação, não devendo ser a autoridade pública demasiadamente rigorosa em seu cumprimento. Assim entende o Desembargador Venício Salles, do TJ de São Paulo, e estudioso do tema:

Não é exigido do Município grande rigor no cumprimento deste item, pois o perfeito enquadramento da área regularizanda aos padrões registrais foi atribuído ao Oficial do Registro de Imóveis. As dúvidas ou incertezas quanto ao mais próprio enquadramento não poderão obstar a expedição do ,auto de demarcação ${ }^{\text {ee }}$. Voltamos aqui a ressaltar o sentido da função social da propriedade, que inverte as prioridades, prestigiando o interesse coletivo em contrapartida com o interesse individual. Prevalece, destarte, o impulso para regularizar que não pode ser frustrado pela imperfeita descrição tabular das antigas glebas (Salles, 2012, p. 5).

Isto porque a averbação do auto de demarcação urbanística só ocorrerá de fato quando decorrer o prazo de 15 dias para sua impugnação, após citados 
pessoalmente o proprietário anterior e os confrontantes por edital, sendo permitida a citação por edital do proprietário quando este não for localizado. Caso haja impugnação, o oficial do registro deverá notificar o Poder Público para que se manifeste no prazo de sessenta dias. Como comenta Salles (2012):

O proprietário tabular poderá impugnar perante a Serventia Imobiliária, apresentando seus motivos e fundamentos, caso em que a Municipalidade será chamada para apresentar suas razões em sessenta (60) dias, podendo corrigir o auto de demarcação ou excluir a área impugnada. Nesse caso a regularização fundiária continuará em face da área não questionada.

Quanto à parte impugnada, Salles (2012, grifos meus) ainda ensina:

O Oficial de Registro de Imóveis possui prerrogativa legal para tentar o "acordo", mas não poderá lançar qualquer tipo de decisão, nem que se limite exclusivamente a critérios técnicos. O conflito de interesse encerra o percurso administrativo, franqueando à Municipalidade ou ao interessado o ingresso judicial. Os interessados poderão, eventualmente, optar pelo caminho do usucapião judicial, preferivelmente plúrimo, alicerçado nas informações constantes da "demarcação" ou no projeto.

$\mathrm{O}$ acordo, portanto, de prerrogativa do oficial de registro, diz respeito ao princípio elencado no artigo 48, IV desta lei: o estímulo à resolução extrajudicial dos conflitos. No espírito de desjudicialização, o legislador previu a faculdade de promover uma espécie de conciliação entre as partes, que só se refletirá nas suas manifestações de vontade, sem ter o oficial exercido qualquer poder de decisão. Ainda, a Lei n ${ }^{\circ} 11.977$ de 2009 alterou o elenco de documentos para averbação em registro de imóveis segundo o artigo 167, II, da Lei de Registros Públicos, prevendo o auto de demarcação urbanística em seu item 26. O projeto de regularização, pronto, também deverá ser registrado.

O auto de demarcação urbanística é o passo inicial no processo de regularização fundiária, uma vez que a partir de seu registro é que o poder público passa a ter o dever de elaborar o projeto do artigo 51. Caso o projeto já tenha sido proposto por interessados que sejam legitimados para tal, o Município poderá complementar e aprovar o documento. Diz o artigo 58: $a$ partir da averbação do auto de demarcação urbanística, o poder público deverá elaborar o projeto previsto $n$ o art. 51 e submeter o parcelamento dele 
decorrente a registro. É o registro deste parcelamento que determina, segundo o $\$ 1^{\circ}$ deste artigo, que o poder público concederá título de legitimação de posse aos ocupantes cadastrados. Aqui, a lei já cria uma possível confusão, não esclarecendo se o registro do plano é o registro do parcelamento, ou se são documentos autônomos. De qualquer forma, chega-se, finalmente, ao título de legitimação da posse. Tal como o auto de demarcação, o título de legitimação de posse passou a constar dentre os títulos registráveis segundo a Lei de Registros Públicos, no item 41.

A legitimação de posse, apesar de remodelada à luz do ordenamento (CF88, CC02 e Estatuto da Cidade), não é instrumento inédito no Direito brasileiro. Marco Aurélio Bezerra de Melo (2011, p. 158-159), resgata a legitimação de posse prevista na antiga Lei de Terras de 1850, em seu artigo $5^{\circ}$, que a permitia quando mansas e pacíficas, adquiridas por ocupação primária, ou havidas do primeiro ocupante, que se achassem cultivadas, ou com princípio de cultura, e morada habitual do respectivo posseiro, ou de quem o represente [...]. Aponta o autor, ainda, que a legitimação da posse na Lei de Terras era, no entanto, limitada, porque a conversão da posse legitimada em propriedade dos bens só poderia ocorrer pela venda e compra e sucessão hereditária, conforme interpretação com o artigo $1^{\circ}$ da referida lei.

Como ensina o Procurador do Estado Miguel Baldez (1997, p.5), além do fato de que a Lei de Terras consolidou os latifúndios através da medição e demarcação das sesmarias outorgadas e ocupações havidas enquanto vigorava o coloniato, a opção pela compra e venda como modalidade única de aquisição de propriedade levou a uma histórica exclusão do trabalhador à titularidade formal de seus imóveis.

Parece-nos que o instituto está a merecer um novo retorno ao direito civil brasileiro como instrumento hábil para regularizar a situação fundiária das favelas, mocambos, palafitas, bem como os loteamentos clandestinos e irregulares que não reúna condições de ser regularizado.

O fato é que o "uso campeão" [usucapião] [...], seja a sua versão individual ou coletiva, não tem tido fôlego suficiente para ganhar o jogo da regularização fundiária de favelas ante ao seu procedimento 
judicial medieval e dificuldades cartorárias e jurídicas de toda ordem (Mello, 2011, p. 159).

Melo (2008, p. 148) ainda indica que até o advento da Lei $n^{\circ} 11.977$ de 2009, a legitimação de posse só havia sido prevista sobre imóvel público, não apenas pela referida Lei de Terras, mas na Medida Provisória n ${ }^{\circ} 2.220$ de 2001 e na Lei no 11.487 de 2001 também. Nota-se aqui que tal instrumento não foi inserido no Estatuto da Cidade, diploma da mesma época.

Assim, na Lei no 11.977 de 2009, a legitimação de posse, agora formalmente definida como ato do poder público destinado a conferir título de reconhecimento de posse de imóvel objeto de demarcação urbanística, com a identificação do ocupante e do tempo e natureza da posse (artigo 47, IV), é o último passo antes da conversão em título de propriedade. Como já assinalado, o título de legitimação de posse será concedido após o registro do parcelamento decorrente do plano ou projeto de regularização. A lei não determina lapso ou prazo para o Poder Público conferir os títulos de legitimação de posse, mas importa dizer que estes títulos também deverão ser registrados no cartório.

A usucapião ressurge neste processo administrativo cinco anos após o registro da legitimação de posse, quando esta se converte em propriedade. É a chamada usucapião administrativa correndo no mesmo prazo que a usucapião especial urbana e com base na mesma limitação de $250 \mathrm{~m}^{2}$ ao imóvel.

Art. 60 Sem prejuízo dos direitos decorrentes da posse exercida anteriormente, o detentor de título de legitimação de posse, após 5 (cinco) anos de seu registro, poderá requerer ao oficial de registro de imóveis a conversão deste título em registro de propriedade, tendo em vista sua aquisição por usucapião, nos termos do artigo 183 da Constituição Federal.

Os parágrafos deste artigo determinam que para converter o título de posse em propriedade é necessária a apresentação (I) de certidões do cartório distribuidor demonstrando a inexistência de ações em andamento que versem sobre a posse ou a propriedade do imóvel, fornecidas pelo poder público; (II) de declaração de que não possui outro imóvel urbano ou rural; (III) de declaração de que o imóvel é utilizado para sua moradia ou de sua família; e, (IV) de declaração de que não teve reconhecido anteriormente o direito à 
usucapião de imóveis em áreas urbanas. Assim, a conclusão do processo de aquisição da propriedade se daria no próprio Registro de Imóveis, presente em todas as etapas do processo.

Em conclusão, cabe argumentar que para garantir o direito social (e fundamental) à moradia, a posse passa a ser um direito legítimo e o Estado passa a ter "o poder-dever de legitimar essa posse com vistas a futuramente atestar a própria propriedade" (Melo, 2008, p. 61). Por isso, os novos contornos dados à legitimação de posse por esta lei - que determinam sua conversão natural em propriedade decorridos cinco anos de seu registro indicam, pela primeira vez no ordenamento brasileiro, uma verdadeira valorização do instituto da posse e seu reconhecimento como forma legítima de acesso à propriedade.

\subsection{Soltando as amarras da ambiguidade: a propriedade como desfeche garantido pelo procedimento administrativo da usucapião}

A Lei $\mathrm{n}^{\circ} 11.977$ de 2009, em suma, cria um procedimento para o reconhecimento da usucapião alternativo à via judicial, que tem por base a cooperação entre as autoridades municipais, os Registros de Imóveis e os beneficiários. Os novos trâmites administrativos criados pela lei - que, ao final, pretendem garantir o título de propriedade - são todos desenvolvidos e validados pelos órgãos da Prefeitura e pelos cartórios de Registro de Imóveis, podendo ser motivados por interessados legitimados para tal. À luz da tradição de ambiguidade das leis fundiárias brasileiras, esta última seção pretende timidamente problematizar o texto da Lei $\mathrm{n}^{\circ} 11.977 / 2009$, com o objetivo de medir seu potencial de transformação da atual situação dos assentamentos urbanos.

A primeira questão que a desjudicialização suscita é, inevitavelmente, a morosidade do Judiciário. Mesmo com a criação de Juizados Especiais para lidar com causas de menor porte, algumas intervenções judiciais ainda 
pareciam desnecessárias. Salvaguardada a inafastabilidade da jurisdição, a tendência de desjudicialização das relações patrimoniais se apresenta como alternativa capaz de desafogar em parte o Judiciário e dar maior celeridade aos processos e homologações simples de cunho cartorial e às resoluções de conflitos de interesses, que podem optar pela arbitragem.

Em relação à usucapião, a Lei $n^{\circ} 11.977 / 2009$ estabeleceu o seguinte procedimento administrativo: por iniciativa própria ou por proposta de projeto pelos interessados, o Município deve registrar um auto de demarcação urbanística da área a ser usucapida e, em seguida, aprovar um projeto de regularização fundiária que também envolve adequação urbanística; registrado o plano e o parcelamento que prevê, o Município poderá outorgar títulos de legitimação de posse para os cadastrados no projeto, que, ao ser também registrado, iniciará a contagem do prazo para a usucapião. O imóvel é usucapido em cinco anos, após os quais bastará a apresentação do título de posse instruído com algumas declarações cartoriais em Registro de Imóveis para a conversão em título de propriedade.

Burocrático, o procedimento administrativo envolve a elaboração de uma série de documentos, a certificação de outros tantos e o registro de todas as etapas no referido Registro de Imóveis. Além disso, não prevê prazos ou metas para as etapas, dependendo todo o processo, portanto, na iniciativa do Município de cumprir com a burocracia: registrar o auto de demarcação, aprovar o plano de regularização e o parcelamento e conferir os títulos de legitimação de posse. É só a partir deste que o processo de titulação se desenvolve naturalmente, apenas com o decorrer do tempo. Portanto, se por um lado, o procedimento pode facilmente ser mais célere que a via judicial, por outro, sua celeridade dependerá do aparato jurídico-burocrático do Município, o que em última instância está ligada à vontade política e prioridades de governo. Ainda neste sentido, a lei mostrou um avanço em relação à lógica do Estatuto da Cidade, que, apesar de prever poderosos instrumentos de 
reordenamento urbano, condicionou sua aplicabilidade à regulamentações e leis supervenientes. Neste sentido estabelece a nova lei:

Art. 49. Observado o disposto nesta Lei e na Lei ${ }^{\circ} 10.257$, de 10 de julho de 2001, o Município poderá dispor sobre o procedimento de regularização fundiária em seu território.

Parágrafo único. A ausência da regulamentação prevista no caput não obsta a implementação da regularização fundiária.

Considerada a evolução legislativa em termos da especificação do Direito Urbanístico, a Lei n 11.977/2009 aparenta ter vencido outros velhos hábitos: o texto da lei é claro sobre os procedimentos que criou, especialmente após as modificações da Lei $\mathrm{n}^{\circ}$ 12.424/2011, que aproximou ainda mais a nova política de parcelamento à realidade urbana brasileira. Em termos de objetivos, a referida lei está voltada especificamente para a regularização fundiária urbana, diferenciando-se assim da Lei de Parcelamento de 1979. Por isso, seus dispositivos tentam abranger as situações de ilegalidade e irregularidade fundiária das mais diversas, orientados claramente para facilitar a obtenção dos devidos títulos e para disseminar a urbanização adequada, integrando estes assentamentos à cidade formal.

Exemplo disso foi o reconhecimento, pela Lei $\mathrm{n}^{\mathrm{o}} 12.424 / 2011$, de situações em que o domínio privado [é] com proprietários não identificados, em razão de descrições imprecisas dos registros anteriores (artigo 56, §5, I), fato que deverá ser indicado no auto de demarcação urbanística a fim de instrui-lo, sem, contudo, obstar a regularização. Na ação judicial de usucapião, é comum que se passem anos antes de se obter uma certidão de citação positiva do proprietário anterior, variando conforme o juiz sua inclinação para a decretação de revelia em casos de réus não localizados ou desconhecidos. Assim, o novo procedimento prevê uma situação frequentemente encontrada na regularização urbana expressamente, impedindo que este detalhe venha a gerar situações irresolúveis.

Neste sentido, a Lei $\mathrm{n}^{\circ} 11.977 / 2009$ quebra, até certo ponto, com a tradição legislativa sugerida por Holston (1993), apesar de não se automatizar completamente, criando mecanismos que garantem a propriedade 
independentemente de manifestação externa ao possuidor. Obtido o título de legitimação de posse, só dependerá do possuidor, gozando de gratuidade de justiça ou descontos cartoriais, registrá-lo e converte-lo quando passados cinco anos. Os possíveis entraves que podem surgir ao longo do processo administrativo que permite a outorga dos títulos de posse também são combatidos na lei, como já assinalam seus primeiro intérpretes. Em relação, por exemplo, o plano de regularização do artigo 51, assinala Venício Salles (2012, p. 5, grifos meus):

Não é exigido do Município grande rigor no cumprimento deste item, pois o perfeito enquadramento da área regularizanda aos padrões registrais foi atribuído ao Oficial do Registro de Imóveis. As dúvidas ou incertezas quanto ao mais próprio enquadramento não poderão obstar a expedição do ,auto de demarcação ${ }^{\text {e. }}$. Voltamos aqui a ressaltar o sentido da função social da propriedade, que inverte as prioridades, prestigiando o interesse coletivo em contrapartida com o interesse individual. Prevalece, destarte, o impulso para regularizar que não pode ser frustrado pela imperfeita descrição tabular das antigas glebas. [...] Desta forma, a planta de sobreposição deverá refletir a área regularizanda e a(s) gleba(s) a ser(em) desfalcada(s), em atenção a critérios e padrões de probabilidade, mormente em face das imperfeições constantes do fólio real. Reafirma-se que a incerteza tabular não pode prejudicar ou emperrar o processo de regularização fundiária.

Assim, o procedimento extrajudicial, pela sua natureza, permite maior flexibilização do cumprimento de exigências burocráticas, estando o Poder Judiciário mais restrito à igualdade de oportunidade entre as partes e as determinações do Código processual. No entanto, a celeridade ou maior simplicidade do procedimento criado pela Lei $n^{\circ} 11.977 / 2009$ cobra o preço de cinco anos, sendo a posse capaz de gerar a propriedade reconhecida a partir do registro de legitimação de posse.

No texto original da lei, estavam previstos como passíveis de regularização fundiária de interesse social os assentamentos irregulares urbanos nos quais tenham sido preenchidos os requisitos da usucapião. No entanto, a Lei $\mathrm{n}^{\circ}$ 12.424/2011 deu nova redação ao artigo 47, VII, alínea a, retirando o termo usucapião, e exigindo apenas que a área esteja ocupada de forma mansa e pacífica há pelo menos cinco anos. Em análise sistemática do nosso 
ordenamento, rapidamente se repara que o emprego do termo usucapião e o reconhecimento do preenchimento de seus requisitos pela autoridade municipal implicariam no imediato reconhecimento da propriedade, uma vez que o direito nasce naturalmente e é apenas reconhecido por sentença ou título.

Sendo assim, o legislador, em realidade, apenas reconhece a posse a partir da intervenção regulatória do Estado, sem considerar a posse anterior, que é o próprio direito de propriedade já adquirido pela caracterização da usucapião. Ora, se a posse mansa e pacífica existe a pelo menos cinco anos e o imóvel não ultrapassar $250 \mathrm{~m}^{2}$, além de preencher os requisitos da Lei $\mathrm{n}^{\circ}$ 11.977/2009 para a regularização de interesse social, o possuidor também preencheu os da usucapião especial urbana, sendo ele, portanto, proprietário desde o início do processo de regularização.

Visto que a morosidade do Judiciário é especialmente condenada em ações meramente declaratórias, por assinalarem direitos constituídos, o procedimento criado pela Lei $n^{\circ} 11.977 / 2009$ mostra-se igualmente perverso, na medida em que poderia ter criado os procedimentos probatórios necessários junto ao Registro de Imóveis para a caracterização da usucapião e a outorga de título de propriedade. No entanto, o legislador optou por condicionar o referido título à realização do procedimento de demarcação urbanística e legitimação de posses. Considerando que a lei não subjuga a conversão da legitimação de posse em propriedade à realização das obras urbanísticas, conclui-se que o procedimento de regularização é mero trâmite complicador entre o possuidor e seu direito ao título. 


\section{Considerações finais}

O desafio diante da regularização fundiária no Brasil é enorme: historicamente concentrada no campo e mercadoria escassa nas cidades, a terra sempre foi arena para conflitos entre classes, entre detentores de direito e entre princípios jurídicos. A questão da terra é a questão da propriedade: nem todos são ou podem ser donos do solo, mas todos precisam de um pedaço dele para viver. Este recurso finito e absolutamente essencial para o desenvolvimento humano, mesmo com a abundância que temos no Brasil, permaneceu historicamente escasso para grande parte da população, que sem o aproveitar com o cultivo, passou a buscá-lo nos centros urbanos, na forma da moradia.

Neste sentido, este trabalho apresentou uma longa análise histórica da formação do sistema fundiário brasileiro do ponto de vista legislativo, entendendo as leis, postas em seus contextos, como retratos da compreensão jurídica da realidade, ilustrações das diferentes correntes e interesses que disputam na arena política, especialmente legislativa. $\mathrm{O}$ que pretendia a partir desta retrospectiva era buscar continuidades e mudanças na forma com que a lei trata a terra no Brasil, valendo-se da leitura de James Holston (1993), que aponta para as ambiguidades intencionais das leis fundiárias em sua interpretação de maior repercussão fora do Direito, como na Sociologia e Filosofia. Com isso, foi possível identificar a lentidão legislativa em se adaptar ao fenômeno da urbanização, evitando tratar de forma direta dos conflitos fundiários e abstendo-se de criar novas formas de inclusão em massa de possuidores irregulares nas cidades. Destaca-se que o próprio Estatuto da Cidade, com todas as suas inovações, pecou, porém, em não garantir maior efetividade de seus dispositivos, permitindo que muitos permaneçam inaplicáveis. Não obstante, restou clara a adaptação do ordenamento aos novos dispositivos, em especial à função social da propriedade, que passou a orientar todos os outros diplomas legais a partir da Constituição de 1988.

Nesta análise também se destacou o papel social da posse e sua inaceitável desvalorização jurídica diante da propriedade. Ganha relevo, 
portanto, a usucapião, como único meio legal de se adquirir a propriedade pela posse. $\mathrm{O}$ desdobramento deste instituto em suas várias modalidades previstas nas leis analisadas aponta para a pluridade de situações em que se demanda a legitimação da posse como propriedade e sua urgência, verificada na diminuição constante dos prazos para a prescrição aquisitiva. Neste contexto, o trabalho tratou das mudanças mais recentes trazidas ao instituto: a desjudicialização da usucapião pela Lei $\mathrm{n}^{\circ} 11.977 / 2009$, que permite seu reconhecimento em Registro de Imóveis, cumpridas as exigências burocráticas.

No entanto, a complexidade do problema enfrentado - o déficit habitacional e as irregularidades nos vastos assentamentos urbanos - afasta qualquer possibilidade de uma solução simples. $\mathrm{O}$ novo procedimento para o reconhecimento da usucapião, portanto, apresenta alternativas à via judicial dotadas de vantagens palpáveis, como a maior celeridade e abertura à pressão dos beneficiários e da sociedade para a sua concretização. A Lei no 11.977 de 2009, portanto, representa grandes avanços legislativos como a primeira lei específica sobre a regularização fundiária urbana, mesmo que, sozinha, não dê conta de resolver o problema do qual trata, como nenhuma lei o poderia fazer. Mesmo assim, é digno de nota que o procedimento instituído por ela á, senão, escolha do legislador, podendo este ter optado por trâmites mais simples de reconhecimento da posse e de outorga de títulos. 


\section{Bibliografia}

AGUIAR, Joaquim Castro. Direito da Cidade. Rio de Janeiro: Ed. Renovar, 1996.

ALBUQUERQUE, A. R. V., Da função social da posse e sua consequência frente à situação proprietária. Rio de Janeiro: Lumen Juris, 2000.

ALFONSIN, Betânia. "O significado do Estatuto da Cidade para os processos de regularização fundiária no Brasil." In: ROLNIK, Raquel (et. al.). Regularização fundiária de assentamentos informais urbanos. Brasília: Ministério das Cidades, 2007. Pp. 68-98.

ARAÚJO, Luiz Ernani. A questão fundiária na ordem social. Porto Alegre: Ed. Movimento, 1985.

BALDEZ, Miguel Lanzellotti. Notas sobre a democratização do processo. Rio de Janeiro: Forense, 1997.

BENEDETTO, Cristiane Siggea; BLANCO, Gabriel Ismael Folgado. "Regularização fundiária de interesse social de loteamentos urbanos e conjuntos habitacionais." In: CARVALHO, Celso Santos; GOUVÊA, Denise; BALBIM, Renato (Coords.). Acesso à terra urbanizada: implementação de planos diretores e regularização fundiária plena. Florianópolis: UFSC; Brasília: Ministério das Cidades, 2008. p. 333-357.

BRASIL. Ministério das Cidades. Secretaria Nacional de Programas Urbanos. Manual de regularização fundiária plena. Brasília, 2007.

CARVAlHO, Vailton L. Formação do Direito Fundiário brasileiro. São Paulo: Ed. Iglu, 1999.

CASTRO, Paulo Rabello. "Que diferença faz um pedaço de papel? A essência humana da propriedade. In: CASTRO, Paulo Rabello (org.). Galo Cantou: a conquista da propriedade pelos moradores do Cantagalo. Rio de Janeiro: Ed. Record, 2011. Pp. 33-41.

CAVALLAZZI, Rosângela Lunardelli. “O Estatuto Epistemológico do Direito Urbanístico Brasileiro: Possibilidades e Obstáculos na Tutela do Direito à Cidade". In: COUTINHO, R. e BONIZZATO, L. (orgs.). Direito da Cidade: novas concepções sobre as relações jurídicas no espaço social urbano. Rio de Janeiro: Lumen Juris, 2007. Pp. 53-69.

CHALUB, Melhim Namem. "O grande teste da usucapião administrativa". In: CASTRO, Paulo Rabello (org.). Galo Cantou: a conquista da propriedade pelos moradores do Cantagalo. Rio de Janeiro: Ed. Record, 2011. Pp. 201214. 
COELHO, M. H. C. O. "O campo na crise do século XIV". In: MEDINA, J. (Dir.) História de Portugal, dos tempos pré-históricos aos nossos dias. Barcelona: Centro Internacional do Livro, v. 3, 1975, p. 233-248.

COMPARATO, Fabio Konder. Direitos e Deveres Fundamentais em Matéria de Propriedade. Revista da Justiça Federal, nº3, artigo 11, 1998. Acessado em: 20 de março de 2012. Disponível em: <http://daleth.cjf.jus.br/revista/numero3/artigo11.htm〉.

CYMBALISTA, Renato. "Política urbana e regulação urbanística no Brasil: conquistas e desafios de um modelo em construção" In: BUCCI, Maria Paula Dallari (org.) Políticas Públicas: reflexões sobre o conceito jurídico. São Paulo: Ed. Saraiva, 2006. Pp. 279-300.

DINIZ, Maria Helena. Curso de Direito Civil Brasileiro. $2^{\circ}$ V. São Paulo: Ed. Saraiva: 2000.

FACHIN, Luiz Edson. A função social da posse e a propriedade contemporânea. Porto Alegre: Sergio Antonio Fabris, 1988.

FARIAS, Cristiano Chaves de; ROSENVALD, Nelson. Direito reais. Rio de Janeiro: Lumen Juris, 2006.

FARIAS, Cristiano Chaves de. O novo procedimento da separação e do divórcio (de acordo com a Lei n. 11.441/07). Rio de Janeiro: Lumen Juris, 2007.

FERNANDES, Edésio. Direito Urbanístico. Belo Horizonte: Del Rey, 1998.

FERNANDES, Edésio. "Perspectivas para a renovação das políticas de legalização de favelas no Brasil." In: ROLNIK, Raquel (et. al.). Regularização fundiária sustentável: conceitos e diretrizes. Brasília: Ministério das Cidades, 2007. Pp. 34-66.

FERNANDES, Edésio. "Regularização de assentamentos informais: o grande desafio dos municípios, da sociedade e dos juristas brasileiros". In: ROLNIK, Raquel (et. al.). Regularização fundiária sustentável: conceitos e diretrizes. Brasília: Ministério das Cidades, 2007. Pp. 18-33.

FERRAZ JR., Tércio Sampaio. "O oficial e o inoficial: ensaio sobre a diversidade de universos jurídicos temporal e espacialmente concomitantes". In: FALCÃO, J. (org.) Invasões urbanas: conflitos de direito de propriedade. FGV, 2008. Pp. 121-144.

GOMES, Orlando. Direito reais. Rio de Janeiro: Forense, 14ª Ed., 1999.

GONÇALVES, Rafael Soares. "Repensar a regularização fundiária como política de integração socioespacial". Estudos Avançados 23 (66), 2009. Pp. 237-250. 
HOLSTON, J. "Legalizando o ilegal: propriedade e usurpação no Brasil". Revista Brasileira de Ciências Sociais, n²1, 1993. Pp. 68-89.

HUBERMAN, Leo. História da riqueza do homem. Rio de Janeiro: Guanabara, 1986.

LIRA, Ricardo Pereira. "Direito Urbanístico, Estatuto da Cidade e regularização fundiária." In: COUTINHO, R. e BONIZZATO, L. (orgs.). Direito da Cidade: novas concepções sobre as relações jurídicas no espaço social urbano. Rio de Janeiro: Lumen Juris, 2007. Pp. 1-15.

LIRA, Ricardo Pereira. Elementos de Direito Urbanístico. Rio de Janeiro: Ed. Renovar, 1997.

MATTOS, Liana Portilho. Nova ordem jurídico-urbanística: função social da propriedade na prática dos tribunais. Rio de Janeiro: Lumen Juris, 2006.

MELO, Marco Aurélio Bezerra de. Legitimação de posse dos imóveis urbanos e o direito à moradia. Rio de Janeiro: Lumen Juris, 2008.

Juris, 2011. Direito das Coisas. Rio de Janeiro: Lumen

MITCHELL, Rafael. "Polêmica da propriedade: quem tem medo de titular a favela?". In: CASTRO, Paulo Rabello (org.). Galo Cantou: a conquista da propriedade pelos moradores do Cantagalo. Rio de Janeiro: Ed. Record, 2011. Pp. 73-83.

RIZZARDO Arnaldo. Promessa de compra e venda e parcelamento do solo urbano. São Paulo: Revista dos Tribunais, 2003.

SALLES, Venício Antonio de Paula. "Usucapião administrativa: Lei 11.977/2009." Disponível em: <http://registradores.org.br/usucapiaoadministrativa-lei- 119772009/>. Acesso em: 20 de março de 2012. (ok)

SANTOS, Boaventura de Sousa. "Notas sobre a História Jurídico-Social de Pasárgada". In: SOUTO, Cláudio e FALCÃO, Joaquim (orgs.). Sociologia e Direito. São Paulo: Ed. Pioneira Thompson Learning, 2002. Pp. 87-95.

SOUZA, Adriano Stanley Rocha. Direito das coisas. Belo Horizonte: Del Rey, 2009.

SILVA, José Afonso. Direito Urbanístico Brasileiro. São Paulo: Ed. Malheiros, 1995.

TEPEDINO, Gustavo. Temas de Direito Civil: Tomo II. Rio de Janeiro: Renovar, 2006. 
"Contornos Constitucionais da Propriedade Privada."

In: DIREITO, Carlos Alberto Menezes (org.) Estudos em Homenagem ao Prof. Caio Tácito. Rio de Janeiro: Ed. Renovar, 1997. Pp. 309-333.

"A Garantia da Propriedade no Direito Brasileiro". In: Revista da Faculdade de Direito de Campo, Ano VI, nº 6, Junho de 2005. Pp. 101-119.

TIGAR, Michael E. \& LEVY, Madeleine. $O$ direito $e$ a ascensão do capitalismo. Rio de Janeiro: Zahar Editores, 1978. 